\title{
Explaining the effect of rapid internationalization on horizontal foreign divestment in the retail sector: An extended Penrosean perspective
}

\author{
Alex Mohr ${ }^{1}$, \\ Georgios Batsakis ${ }^{2,4}$ and \\ Zita Stone ${ }^{3}$

\footnotetext{
${ }^{1}$ Vienna University of Economics and Business, Welthandelsplatz 1, 1020 Vienna, Austria; ${ }^{2}$ ALBA Graduate Business School, The American College of Greece, 6-8 Xenias Str, 11528 Athens, Greece; ${ }^{3}$ Kent Business School, University of Kent, Room 319, Sibson Building, Canterbury, Canterbury, Kent, UK; ${ }^{4}$ Brunel University London, Kingston Lane, Uxbridge, Middlesex UB8 3PH, UK
}

Correspondence:

A Mohr, Vienna University of Economics and Business, Welthandelsplatz 1, 1020 Vienna, Austria.

Tel: +43-1-31336-4547;

Fax: +43-1-31336-905978;

e-mail: alexander.mohr@wu.ac.at

Received: 29 August 2016

Revised: 3 November 2017

Accepted: 3 December 2017

Online publication date: 7 February 2018

\begin{abstract}
We adopt a Penrosean perspective to study the effect of rapid international expansion on the subsequent divestment of international operations. We draw on regional strategy theory and differentiate Penrosean managerial resources by their geographical fungibility to argue that the effect of rapid international expansion on the divestment of international operations varies with the regional patterns of firms' international expansion and international experience. We test our hypotheses using two-stage least squares (2SLS) estimation on data that capture the international expansion and divestment of retailers over the period 2003-2012.
\end{abstract}

Journal of International Business Studies (2018) 49, 779-808.

https://doi.org/|0.1057/s41267-017-0138-0

Keywords: foreign divestment; managerial resources; penrose effect; regional strategy theory; internationalization speed; retailers

The online version of this article is available Open Access

\section{INTRODUCTION}

Penrose (1959) argued that limited managerial resources constitute the key factor restraining the growth of firms (Kay, 1999; Pitelis, 2007). Although she does not provide an in-depth discussion of the managerial resources that are central to her argument, Penrose (1959) clearly indicates that managerial resources and the services these resources can provide are not homogenous and that they are shaped by the particular context in which these resources are employed. Managerial resources are thus likely to be only imperfectly fungible across contexts.

We analyze the geographic fungibility of managerial resources and services by studying the effect of rapid firm internationalization on the subsequent divestment of international operations. We view foreign divestment as an extreme variant of the Penrose effect, that is, the slow-down in growth after periods of rapid firm growth (Mahoney \& Pandian, 1992; Penrose, 1959). Investigating this effect in the context of firms' international growth, Tan and Mahoney (2005), for 
example, demonstrate that the Penrose effect exists for Japanese firms that slow their expansion in the US market after periods of rapid expansion there. Although existing research has raised the possibility of firms ignoring and breaching Penrosean limits (Hoskisson \& Turk, 1990; Markides, 1992, 1995), it has yet to account for the possibility that rapid expansion in one period leads to a breach of Penrosean constraints. ${ }^{1}$ Foreign direct investment allows firms to release and redeploy managerial resources if rapid international expansion has created demands that the firms' existing managerial resources cannot meet in the short term - a breach of Penrosean constraints - because recruitment and training of new managers take time (Penrose, 1959).

Because the managerial resources and services required for certain expansion patterns may differ from those that can be released through the divestment of particular international operations, the effect of rapid internationalization on the subsequent divestment of international operations will vary with the degree to which a firm's managerial resources can provide the services required by a particular international expansion path. Building on the insights of regional strategy theory and the likely limits on the inter-regional fungibility of firm resources (Arregle, Miller, Hitt, \& Beamish, 2016; Asmussen, 2012; Rugman, 2005; Rugman \& Verbeke, 2004, 2005), we suggest that the regional patterns of firms' international expansion and international experience will moderate the effect of rapid internationalization on foreign divestment. Regional strategy theory suggests that because environments tend to be more similar within geographic regions than across them, expanding within a single region is easier than expanding across regions (Rugman, 2005; Rugman \& Verbeke, 2004, 2005). Firms that rapidly internationalize within a single region, as opposed to across different regions, are therefore less likely to breach Penrosean limits and experience the associated inefficiencies. Intra-regional concentration will thus weaken the link between internationalization speed and subsequent overseas divestment. This effect is in line with Penrose's (1959) suggestion that growth in familiar market areas will require less effort and leads to fewer operating problems than growth in market areas that are new to a firm. Accounting for the region-specific characteristics of managerial resources and their limited fungibility across geographic regions, we also suggest that rapid international expansion within (outside) a firm's home region will be particularly relevant for a firm's foreign divestment within (outside) its home region.

Further, the level of services that a firm's managerial resources can provide will depend on the experience of the firm's managers. Because firms with internationally experienced managers will have developed the routines and skills required for international expansion (e.g., Clarke, Tamaschke, \& Liesch, 2013), these firms will be less likely to breach Penrosean limits when internationalizing rapidly than will firms without international experience. Therefore, international experience is likely to reduce the strain on managerial resources and thus weaken the effect of rapid internationalization on subsequent international divestment. Additionally, however, Penrose (1959) emphasized that the context in which managerial resources accrue experience shapes the particular nature of this experience and thus affects the services that these managerial resources can provide. In particular, prior research suggests that international experience and the associated knowledge may be location-bound (e.g., Hutzschenreuter \& Matt, 2017; Luo \& Peng, 1999), and regional strategy theory highlights the regionboundedness of international experience (Oh, Sohl, \& Rugman, 2015). International experience obtained by operating within (outside) a firm's home region is particularly relevant in shaping the relationship between a firm's rapid internationalization within (outside) its home region and foreign divestment within (outside) its home region.

By studying how rapid internationalization affects subsequent overseas divestment and how the regional patterns of firms' international expansion and international experience may shape this effect, we contribute not only to the development of Penrosean logic but also to our understanding of the drivers of international divestment. Although Penrose's theory has been influential, it remains "incomplete and unsatisfactory in certain aspects" (Kay, 1999, p. 78), leading to calls for its further development and refinement (Pitelis \& Verbeke, 2007). We respond to these calls by theorizing about differences in managerial resources and their geographic fungibility as key factors in firm (de)internationalization. In developing our argument, we provide an explicit clarification and justification of hitherto implicit assumptions about the release of managerial resources that underlie the use of Penrosean logic in existing research (Helfat \& Eisenhardt, 2004; Roberts \& McEvily, 2005). This finer-grained characterization of managerial resources allows us to extend research explaining firm internationalization patterns using Penrosean 
logic with an explanation of foreign divestment and to identify important boundary conditions of Penrosean logic in the context of firm (de)internationalization.

Explaining foreign divestment based on Penrosean logic and insights from regional strategy theory allows us to advance theoretical explanations for why firms divest overseas operations (Benito, 2005; Benito \& Welch, 1997; Berry, 2010; Boddewyn, 1979). Despite the growing interest in the drivers of divestment of foreign subsidiaries (Barkema, Bell, \& Pennings, 1996; Belderbos \& Zou, 2006, 2009; Benito, 1997; Berry, 2013; Dai, Eden, \& Beamish, 2013; Li, 1995; Soule, Swaminathan, \& Tihanyi, 2014; Tsang \& Yip, 2007; Wan, Chen, \& Yiu, 2015), theoretical explanations of foreign subsidiaries' divestment remain scarce compared with explanations of such subsidiaries' establishment. This is particularly the case for explanations of foreign divestment that account for the resource interdependencies within a firm's portfolio of international operations (e.g., Beamish \& Lupton, 2016) and the path dependence of international expansion (Hutzschenreuter, Voll, \& Verbeke, 2011).

We examine our hypotheses using data on the horizontal international expansion and foreign divestment activities of large retailers from 2003 to 2012. Although the retail sector remains neglected compared to the attention given to other sectors, a growing stream of research has focused on retailers' internationalization (Alexander \& Myers, 2000; Sternquist, 2007). A small number of studies have investigated foreign divestment in the retail sector, but these studies primarily analyze individual cases of retail divestment (Gielens \& Dekimpe, 2007; Gripsrud \& Benito, 2005; Huang \& Sternquist, 2007) or describe foreign divestment activities in the retail sector (Alexander, Quinn, \& Cairns, 2005). The retail industry is particularly suitable for testing our hypotheses because retail firms expand primarily through horizontal international expansion, increasing the importance of the release and redeployment of managerial resources that are central to our argument.

\section{THEORETICAL BACKGROUND AND HYPOTHESES}

\section{The Effect of Internationalization Speed on Foreign Divestment}

Firms' rapid international expansion can lead to a breach of Penrosean constraints on efficient expansion. Although most research applying Penrosean thinking in the context of international firm growth has (implicitly) treated Penrosean constraints as unbreachable or at least as unlikely to be breached by rational decision makers (Hutzschenreuter, Voll, \& Verbeke, 2011; Verbeke \& Yuan, 2007), some authors raise the possibility that firms might ignore these constraints and suffer negative effects (Slangen, 2016; Tan, 2003). A breach of Penrosean constraints may be attributable to the difficulties of correctly assessing the demands that rapid internationalization places on a firm's managerial resources and the level and nature of managerial resources available to satisfy those demands. Penrose (1959) emphasizes that firms' decisions about investment programs are based on their subjective expectations about an uncertain future. Rapid internationalization may also be driven by a desire either to rapidly rebalance a firm's portfolio of operations from declining to more promising markets or to learn about the potential of different product markets or regional markets through trial and error (Mariotti \& Piscitello, 1999; Penrose, 1959). In such cases, a firm's decision makers may accept the potential negative effects of breaching Penrosean constraints on efficient growth. Finally, firms may engage in overly rapid international expansion out of a desire to achieve first-mover advantages and for the same reasons that lead firms to over-diversify, i.e., because of managers' self-serving behavior, managerial hubris, or incorrect signals and incentives from the capital market (Markides, 1995).

A breach of Penrosean constraints means that available managerial resources are no longer able to satisfy organizational demands for planning and integrating and for learning from overseas operations due to managers' limited time and capacities. Breaching Penrosean constraints thus exacerbates the time compression diseconomies associated with accelerating international expansion (Jiang, Beamish, \& Makino, 2014; Vermeulen \& Barkema, 2002). Firms that spend insufficient time planning an international expansion are more likely to make errors, for instance, with regard to market selection. Rapid internationalization reduces the time available to managers to collect and assess information about overseas expansion, thereby increasing the likelihood of incorrect assessments and suboptimal decisions (Vermeulen \& Barkema, 2002). From a Penrosean perspective, firms' choice of target markets depends on the existence of local resources and knowledge that 'can add value to firms' existing 
resources, knowledge and technological bases and (thus) operations" (Pitelis, 2007, p. 211). The incorrect assessment of such local resources and knowledge increases the probability that rapidly established overseas operations will fail to add this value.

Rapid internationalization also increases the strain on managerial resources by increasing coordination requirements. Prior research on divestitures (in general) from a principal-agent perspective highlights inadequate internal governance as a driver of such divestitures (Hoskisson, Johnson, \& Moesel, 1994). Analyzing the effects of excessively rapid firm growth, Slater (1980, p. 521) suggests that such growth "causes loss of coordination throughout the enterprise, with both overhead and current costs being higher than they might otherwise have been." Similarly, rapid international expansion reduces firms' ability "to evaluate their foreign experience, assimilate it, and apply it to commercial ends" (Vermeulen \& Barkema, 2002, p. 640). Therefore, firms are less likely to benefit from international operations that they have established rapidly.

We suggest that these consequences of rapid internationalization will increase the likelihood of foreign divestment. Although some of these effects are also likely to affect firm performance, which in turn may increase the likelihood of divestment (Hamilton \& Chow, 1993), a decline in performance need not manifest before firms decide to divest. The negative consequences of internationalization usually manifest themselves before affecting firm performance. Such negative consequences may relate to operational problems and inefficiencies and/or slower than expected market penetration due to, for example, suboptimal decisions regarding outlet locations (see, for instance, Palmer, 2005; Palmer \& Quinn, 2007). Rapid internationalization may therefore lead to foreign divestment even before firm performance is affected. $^{2}$

Overall, breaching Penrosean limits through rapid internationalization makes suboptimal decisions more likely, increases coordination requirements, and hinders the assimilation and exploitation of the foreign experience of overseas operations. Firms may not anticipate these effects when they decide to engage in rapid internationalization because of the difficulties inherent in assessing both the demands associated with rapid internationalization and the ability of managerial resources to meet those demands. Once such effects occur, however, firms can address these negative effects by divesting international operations to realign the scope of international operations with the available managerial resources after a rapid international expansion. Similarly, in the context of product diversification, Penrose (1959, p. 149) suggests that expansion programs may cause "problems of administrative organization," which in turn may lead to the divestment of product lines to rectify firm mistakes.

Prior research on firms' product diversification has highlighted how firms can use the divestment of operations to release (managerial) resources to bring firm size back in line with limited managerial capacity after they have over-diversified (Markides, 1995; Penrose, 1959). Firms also use divestment to reallocate resources to new or more promising product lines (e.g., Helfat \& Eisenhardt, 2004; Roberts \& McEvily, 2005) or markets (Arregle, Beamish, \& Hébert, 2009; Chan, Makino, \& Isobe, 2006), given the trade-offs in the use of limited firm resources in general and limited managerial resources in particular (Levinthal $\& W u, 2010$ ). In a similar vein, foreign divestment allows firms to release managerial resources and ease the strain on managerial resources following periods of rapid international expansion. Because of trade-offs in the use of managerial resource across markets, divestment allows for reallocation of managerial time and attention to more promising markets (Berry, 2010). Similarly, case-based evidence from retailers highlights the role of divestment from overseas operations as a means for retailers to "free up" and redirect resources to other markets (Alexander, Quinn, \& Cairns, 2005, p. 19).

Although prior research highlights the release of managerial (and other) resources through the divestment of operations, such research implicitly assumes that divestment allows for the immediate release of resources dedicated to the divested operations and their subsequent transfer to other parts of the organization (Chan, Makino, \& Isobe, 2006). ${ }^{3}$ Although the activity of divesting overseas operations can itself be expected to require managerial resources (Cairns, Doherty, Alexander, \& Quinn, 2008), research into the process of divesting overseas operations in general (e.g., Ghertman, 1988) and retail outlets in particular (e.g., Cairns, Doherty, Alexander, \& Quinn, 2008) suggests that the type of resources needed to manage divestments differs from the managerial resources needed to plan, establish, and coordinate a firm's (other) overseas operations. This research indicates that 
divestments require higher levels of technical (e.g., accountants) or external staff (e.g., lawyers, consultants) and fewer of the internally experienced managerial resources that are central to the Penrosean argument. Although certain managerial resources may continue to be involved in the divested operations until the divestment process is complete, divestment should allow a firm to release most of the managerial resources associated with the divested operations. ${ }^{4}$ We thus suggest that although divestment will require managerial resources, in most cases divesting overseas operations will lead to a relatively rapid net release of managerial resources. Thus divesting operations can be a result of easing the strain on firms' managerial resources associated with the rapid international expansion of their operations. Accordingly, we formulate the following hypothesis:

Hypothesis 1: The likelihood of divestment of international operations increases with the speed of firms' prior international expansion.

\section{The Role of the Regional Pattern of Firms' International Expansion}

Although Penrose regards the international growth of firms as limited by the same factors as their domestic growth, she emphasizes the similarity between a firm's direction of growth and its existing activities as a key influence on the level of managerial resources needed for that growth (Penrose, 1959, Verbeke \& Yuan, 2007). Specifically, she suggests that firms growing in familiar market areas will experience fewer operating problems and require fewer managerial services than firms growing in unfamiliar markets. As an example, Penrose (1959) highlights differences between countries (e.g., differences in regulatory systems) that affect firms' domestic-versus-international expansion (Pitelis, 2007). Similarly, regional strategy theory (Rugman, 2005; Rugman \& Verbeke, 2004) suggests that firms expanding outside their home region must cope with the liability of inter-regional foreignness, which exceeds the liability of intraregional foreignness encountered when firms expand internationally within their home region (Qian, Li, \& Rugman, 2013; Rugman \& Verbeke, 2007). Because expansion into less familiar market areas requires greater input of managerial resources to obtain and evaluate information (Penrose, 1959), firms expanding internationally within their home regions require fewer managerial resources than firms expanding outside their home regions. Thus firms undergoing rapid international expansion within their home regions are less likely to breach Penrosean limits and subsequently be forced to divest international operations.

Mistakes are more likely when planning interregional than when planning intra-regional international expansion and when making decisions related to inter-regional international expansion, including decisions regarding the adjustment of products, services, and processes. Because firms are more familiar with market conditions within their home region than with those outside their home region, fewer managerial resources are required to plan intra-regional expansion than inter-regional expansion. Accelerating planning processes as part of rapid internationalization will thus lead to lower time compression diseconomies when firms expand intra-regionally rather than inter-regionally. The effect of rapid internationalization on divestment should thus be weaker for firms with high levels of intra-regional concentration.

Furthermore, the greater similarity of conditions between countries within a particular region than between countries in different regions facilitates the integration of rapidly established overseas operations. Because expansion into similar markets puts less strain on managerial resources than expansion into dissimilar markets (Banalieva \& Dhanaraj, 2013, Hutzschenreuter, Voll, \& Verbeke, 2011), rapid expansion into similar markets is associated with less strain on firms' managerial resources. Greater dissimilarity of conditions outside a firm's home region also results in "lower value attributed by consumers ... to the MNE's proprietary - and internationally transferable knowledge" and to greater difficulties in "transferring this proprietary knowledge if it is tacit" (Pitelis \& Verbeke, 2007, p. 143). Similarly, Pitelis and Verbeke (2007) suggest that institutional dissimilarity increases the bounded rationality constraints on decision makers, leading to greater problems of coordination and increasing the requirement for managerial resources. In contrast, the greater institutional similarity between a firm's home and host countries when expanding intra-regionally facilitates the integration and coordination of overseas operations (Verbeke \& Yuan, 2007). Intra-regional expansion thus reduces the need for managerial resources, reducing the likelihood that rapid international expansion will lead to a breach of Penrosean constraints. 
Finally, firms that expand rapidly within, rather than outside of, their home region will also experience fewer negative effects of rapid internationalization on their ability to learn from overseas operations; therefore, such firms will have fewer reasons to divest their overseas operations. Prior research emphasizes the "complementarity between each affiliate's contribution to non-location-bound FSA creation and its location-bound FSA development, as a pre-condition for new technology adoption inside the broader MNE network" (Pitelis \& Verbeke, 2007, p. 144). Because subsidiaries outside of a firm's home region will have a greater need to create the location-bound knowledge that allows them to be nationally and regionally responsive while experiencing greater difficulties in doing so (Rugman \& Verbeke, 2004), they are thus less likely to contribute than subsidiaries within a firm's home region. Intra-regional concentration will therefore attenuate the negative effect of rapid internationalization on a firm's ability to learn from its overseas operations.

Because of the lower strains on managerial resources associated with operating within rather than across regions, firms that have expanded rapidly within their home region experience less strain on their managerial resources than do firms that have expanded rapidly overseas across regions. For these firms, rapid internationalization is thus less likely to lead to a breach of Penrosean constraints on efficient growth that would require a reversal of the rapid expansion or diversion of managerial resources away from other international operations to provide the resources necessary for rapid expansion. Accordingly, we formulate the following hypothesis:

Hypothesis 2: Intra-regional concentration of firms' prior international expansion will weaken the effect of rapid internationalization on subsequent foreign divestment.

The moderating effect suggested in our second hypothesis relates to the effect of a firm's intraregional concentration at a single point in time. However, a firm may expand at different speeds within and outside its home region, which may in turn have different effects on divestment within and outside the home region. The managerial resources released through the divestment of operations within a firm's home region and the services that these resources can provide are likely to differ from the resources released through the divestment of operations outside the firm's home region. Research has highlighted the differences in firms' human resource practices across regions and the greater similarity of resource management practices within a region (Collinson \& Rugman, 2008; Verbeke \& Asmussen, 2016); thus, there are likely differences in managerial resources across regions.

Regional strategy theory also suggests that international expansion outside a firm's home region is associated with significantly greater challenges than expansion within a firm's home region because of "discontinuities of distance at the regional boundary" (Verbeke \& Asmussen, 2016, p. 1055). The managerial resources and services needed to manage rapid internationalization outside a firm's home region differ from those needed to manage rapid internationalization within a firm's home region. In addition to regional institutions that facilitate the international mobility of human resources within but not across regions (Verbeke \& Asmussen, 2016), the inter-regional differences in managerial resources and the services that they can provide make these resources imperfectly fungible across regions, i.e., these resources and their services are region-bound. Therefore, a firm's ability to reallocate managerial resources and their services across regions is likely to be limited. Referring to employees in general, Collinson and Rugman (2008) demonstrate that employees are more mobile within regions than across regions.

Due to the region-boundedness of firms' managerial resources and the services that these resources can provide, the managerial resources released through divestment of operations outside a firm's home region may be of little use in reducing the constraints associated with rapid internationalization within a firm's home region, and vice versa. Consequently, rapid expansion within (outside) the firm's home region may require the release of resources with skills that are relevant to such expansion and thus lead to the divestment of operations within (outside) the firm's home region. Accordingly, we formulate the following hypothesis:

Hypothesis 3: Intra-regional (inter-regional) internationalization speed will have a positive effect on intra-regional (inter-regional) foreign divestment but not on inter-regional (intra-regional) foreign divestment. 


\section{The Role of Firms' International Experience and Its Regional Nature}

Experiential learning plays a central role in Penrose's theory of firm growth because it determines the productive services that can be provided by a firm's managerial resources (Penrose, 1959). Because the managerial resources of internationally experienced firms can provide enhanced managerial services, such firms will experience lower strains when expanding rapidly and will be better at managing these strains. Such firms will thus experience lower diseconomies of time compression when internationalizing rapidly than firms with little or no international experience. Therefore, such firms will feel less of a need to reduce strains by releasing managerial resources through foreign divestment. We thus expect the effect of internationalization speed on international divestment to be weaker for firms with international experience than for firms without such experience.

First, international experience - i.e., the "experience that firms accrue from operating internationally" (Clarke, Tamaschke, \& Liesch, 2013, p. 265) provides firms with the expertise to assess and select opportunities for international expansion. Internationally experienced firms can thus avoid (or at least reduce) the likelihood of making mistakes associated with spending insufficient time on planning an overseas expansion. The limited time for planning and analyses associated with rapid internationalization is thus less likely to result in incorrect assessments and decisions for internationally experienced firms than it is for firms lacking such experience. International experience will thus reduce the likelihood that rapid internationalization will be associated with mistakes during the planning stage that may lead to the divestment of foreign operations.

Second, through international experience, firms will be able to develop processes and routines for integrating and coordinating overseas operations (e.g., Steen \& Liesch, 2007). Rapidly internationalizing firms that have such processes and routines in place will thus experience less strain on their managerial resources than will firms that have not developed such processes and routines because of their lack of international experience. Rapid internationalization will therefore result in lower costs of integrating and coordinating overseas subsidiaries for internationally experienced firms than for firms without such experience. Similarly, firms with higher levels of international experience are better and faster at overcoming their liability of foreignness (Barkema, Bell, \& Pennings, 1996, Delios \& Beamish, 2001; Gao \& Pan, 2010). Compared with firms without international experience, more experienced firms are thus less likely to experience the same level of time compression diseconomies associated with spending insufficient time on integrating and coordinating new subsidiaries, thus weakening the effect of internationalization speed on international divestment.

Third, international experience can act as a "knowledge absorption" facilitator that increases a firm's overall absorptive capacity (Gunawan \& Rose, 2014). High levels of international experience will improve a firm's absorptive capacity, in turn facilitating and potentially accelerating the process of acquiring important knowledge and information. Therefore, internationally experienced firms will be less likely to suffer from the negative effects of rapid internationalization on firms' ability to learn from and add value through their overseas operations (Pitelis \& Verbeke, 2007; Vermeulen \& Barkema, 2002). For internationally experienced firms, the effect of rapid internationalization on the divestment of international operations should thus be weaker.

Overall, international experience is likely to weaken the effect of rapid internationalization on foreign divestment by enabling firms to reduce the strain of rapid internationalization on managerial resources. Therefore, internationally experienced firms are less likely to breach Penrosean constraints on efficient growth when rapidly expanding internationally. Consequently, these firms will be less likely to reverse decisions made during rapid expansion or to divert managerial resources from other international operations to provide the resources needed for rapid international expansion. Accordingly, we formulate the following hypothesis:

Hypothesis 4: Firms' international experience will weaken the effect of rapid internationalization on subsequent foreign divestment.

Penrose (1959) emphasized that the context in which managerial resources accrue experience shapes the particular nature of this experience and thus affects the services that these managerial resources can provide. Similarly, prior research on firm internationalization suggests that the relevance of firms' experiential knowledge for (further) international expansion may vary depending on the source of this knowledge, i.e., on firms' 
geographical patterns of internationalization (Barkema, Bell, \& Pennings, 1996; Luo \& Peng, 1999). Following this logic, research adopting regional strategy theory suggests that because of their region-boundedness, "experience and knowledge gained in domestic and home-region countries cannot readily be transferred to operations in countries outside the home region" (Oh, Sohl, \& Rugman, 2015, p. 223). Thus, we suggest that the services provided by a firm's managerial resources are likely to be (or to be regarded by firms as) region-bound. Specifically, a firm's ability to expand rapidly within (outside) its home region will increase with its experience operating within (outside) its home region. Thus, international experience obtained by operating in countries within (outside) a firm's home region will be particularly useful in reducing the particular strains of rapid internationalization within (outside) its home region, thereby weakening the effect that rapid internationalization has on subsequent foreign divestment within (outside) its home region. Accordingly, we formulate the following hypotheses:

Hypothesis 5a: International experience obtained in the home region will weaken the effect of the speed of international expansion within the home region on subsequent foreign divestment within the home region.

Hypothesis 5b: International experience obtained outside the home region will weaken the effect of the speed of international expansion outside the home region on subsequent foreign divestment outside the home region.

\section{DATA AND METHODS}

\section{Sample}

Our research sample consists of the largest retail MNEs with an international presence in one or more foreign markets from 2003 to 2012 . The main source of our data is the PlanetRetail database. This database provides information on more than 9000 retailers across 211 countries. Given the large number of retail firms without international operations reported in the database, we focused our search on three company rankings: (i) PlanetRetail's Top Global 250 Retailers (2012), (ii) Deloitte's Top 250 Global Retailers (2011), and (iii) UNCTAD's ranking list of the top 100 transnational corporations (2012). The amalgamation of internationally operating firms listed in at least one of these rankings resulted in 189 large retail firms with international operations. For these firms, we extracted data for a 10-year period (2003-2012) from the PlanetRetail database. We complemented these data with financial information from the ORBIS database. However, because ORBIS provided limited or no information about some of the sample firms, our final sample consists of 120 international retailers. To test for sample selection biases, we tested for differences ( $t$ test) in firm size between the original 189 and the final 120 retailers, but there was no statistically significant difference. We also compared the distribution by home country across these two groups and found no marked differences. The retail firms are MNEs that generate sales in one or more retail segments, including grocery, electrical and office, food service, clothing and footwear, leisure and entertainment, health and beauty, and home and garden.

\section{Measures}

Prior studies researching the determinants of overseas divestment use either a dummy representation of divestment based on whether a subsidiary has been divested (Berry, 2013; Song, 2014; Soule, Swaminathan, \& Tihanyi, 2014) or a count representation measuring divestment as the number of divested subsidiaries in a given period (Berry, 2010; Haynes, Thompson, \& Wright, 2002). We suggest that a scale measure that accounts not only for the number of a firm's divested foreign subsidiaries but also for the total number of its subsidiaries is a more precise and comprehensive measure. We therefore measure overseas divestment using the ratio of divested foreign outlets to the total number of outlets in a given year. To test Hypotheses 3 and 5, we split the foreign divestment variable into foreign divestment within the firm's home region and foreign divestment outside the firm's home region, defining regions in accordance with the broad triad (i.e., North America, Europe and Asia) specified by Rugman and Verbeke (2004).

We measure our independent variable - i.e., internationalization speed - as the average number of foreign outlets established by a retailer over the 2 years preceding the observation year. Our measure of internationalization speed thus captures retailers' recent international expansion. ${ }^{5}$ We also test an alternative measure of internationalization speed that captures the speed of retailers' expansion over a longer term using the average number of foreign outlets divided by the number of years since 
the firm's first international expansion (Chang \& Rhee, 2011; Vermeulen \& Barkema, 2002). We discuss the results for this alternative measure below. To test the regional effects, we also split internationalization speed into internationalization speed within a firm's home region and internationalization speed outside a firm's home region, again using the broad triad regions defined by Rugman and Verbeke (2004).

We measure our first moderating variable, intraregional concentration, as the ratio of a firm's sales inside the home region to its total sales (e.g., Oh \& Rugman, 2012). To determine whether a particular country belongs to the firm's home region, we consider the broad triad regions (North America, the European Union and Asia Pacific) defined by Rugman and Verbeke (2004). The second moderating variable, international experience, is calculated as the total number of years that a retailer has operated in each foreign country (Mohr, Fastoso, Wang, \& Shirodkar, 2014). For example, a US retailer that has been operating in the UK for 3 years and in Canada for 7 years would have a cumulative score of ten. To test Hypothesis 5, we split this variable into international experience obtained within a firm's home region and international experience outside a firm's home region, again defining regions in terms of the broad triad.

We include a number of firm- and country-level variables that might affect a firm's decision to divest its foreign operations. Prior research highlights the role that both ownership- and establishment modes play in determining the survival of overseas subsidiaries (Benito, 1997; Hennart, Kim, \& Zeng, 1998; Li, 1995). We thus control for whether a retailer has expanded through an acquisition by including a dummy that takes the value of " 1 " if a retailer has acquired another retailer or the assets of another retailer in a particular year, and " 0 " otherwise (similarly, see Hutzschenreuter \& Voll, 2008). To capture the effects of different ownership strategies, we include a dummy variable to control for whether a retailer enters overseas markets through international franchise, given the importance of franchising in the retail sector. We collected information for these variables from a variety of sources, including corporate websites, annual reports, and reports in the business press (for example, Bloomberg, Reuters, and Forbes).

In line with prior studies (e.g., Chang, Chung, \& Moon, 2013), we measure intangible assets as the ratio of intangible fixed assets to total assets for all sample firms in the given year. We control for leverage as the ratio of a firm's total debts to total assets. Firm age is calculated as the year of observation minus the year of inception (e.g., Baum, Schwens, \& Kabst, 2015). Given suggestions that the level of firm diversification influences the likelihood of divestment (Berry, 2013; Markides, 1995), we control for firms' product diversification using Jacquemin and Berry's (1979) entropy measure suggested in prior research (e.g., Wiersema \& Bowen, 2008). This measure uses the share of a retailer's total sales for each of the following twelve product lines, which are distinguished on the Planet Retail database: automotive products; clothing, footwear and jewelry; consumer electronics; do-it-yourself (DIY) and furniture; edible groceries; entertainment; food service; health and beauty; household and pet care; office supplies; sports and leisure; and other.

To control for non-managerial firm slack resources, we include firm profitability, measured as return on assets (e.g., Hitt, 1997), and cash slack, measured as the firm's amount of cash and cash equivalent reserves minus the industry average amount of cash and cash equivalent reserves (in billion dollars) (Mousa \& Reed, 2013). We control for firm size because research shows that small firms are more likely to divest their foreign operations (Berry, 2013; Chen \& Wu, 1996; Soule, Swaminathan, \& Tihanyi, 2014). In line with past research, we measure firm size as the natural logarithm of firms' total assets (Cui, Meyer, \& Hu, 2014). We measure a firm's market position as a proxy for the competitive pressure experienced by a firm. We calculate this variable as the ranking difference (in terms of sales) between a firm and the market leader in their respective retail segments. Accordingly, the greater (smaller) this difference, the weaker (stronger) the market position and the stronger (weaker) the competitive pressure experienced by a retailer in its market segment.

Finally, we include two country-level control variables. Given indications of the effect of cultural distance on the survival for foreign subsidiaries (Barkema, Bell, \& Pennings, 1996), we incorporate the measure of added cultural distance by calculating the cultural distance between a newly entered country and all countries in which a firm already operates and then taking the smallest of these distances (Hutzschenreuter, Kleindienst, \& Lange, 2014; Hutzschenreuter \& Voll, 2008). To calculate this measure, we use the formula developed by Kogut and Singh (1988) and the cultural values reported by Hofstede (2001). We also include home 
Table 1 Variables, definitions, and data sources

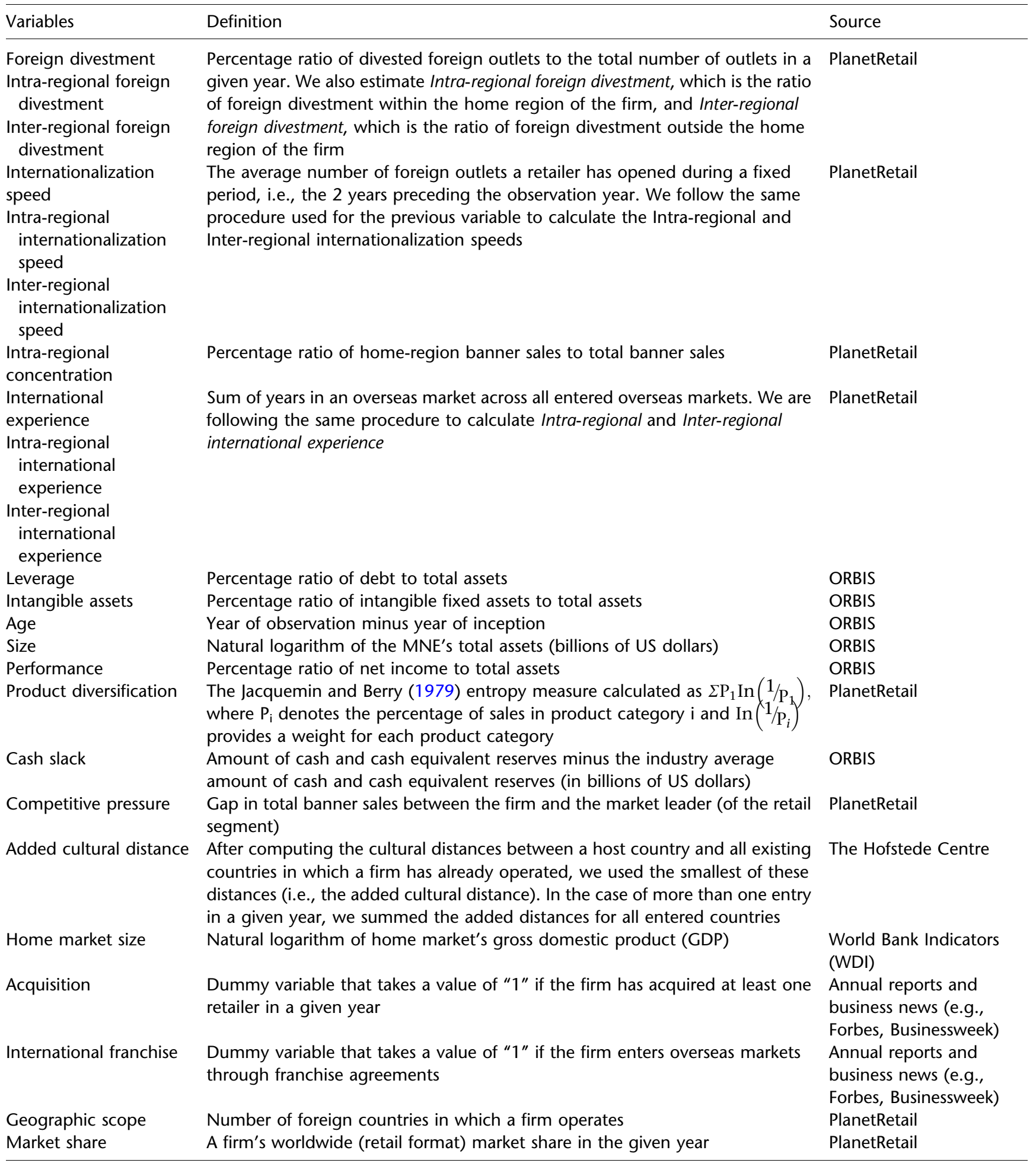

market size by taking the natural logarithm of the home country's gross domestic product (GDP). Table 1 provides the variable definitions and data sources.

\section{Methodology}

Our study aims to examine the effect of MNEs' past internationalization speed on subsequent foreign divestment. Internationalization speed is likely to 
be endogenous because it is determined (partly) by unobserved variables that may also affect firms' subsequent foreign divestment. Firms might follow either a trial-and-error, exploratory approach to expansion (Penrose, 1956; Tran, Santarelli, \& Zaninotto, 2015) or an opportunistic strategy (e.g., Dawson, 2001) and decide simultaneously on rapid international expansion and (subsequent) withdrawal from markets that provide only temporary opportunities. Because of this endogeneity, generalized least squares (GLS) estimations might lead to biased results. A Durbin-Wu-Hausman (DWH) test of endogeneity (Davidson \& MacKinnon, 1993) confirmed that the GLS parameters would indeed deliver biased estimates $(p<0.05)$. Therefore, to test the predicted relationships, we used a two-stage least squares instrumental variable (2SLS IV) random effects model (Wooldridge, 2010). In the first stage of our 2SLS model, the endogenous variable (i.e., internationalization speed) is estimated based on two instrumental variables (alongside the other independent and control variables). In the second stage of the 2SLS model, we use the predicted value from the first stage instead of the endogenous regressor to estimate the effect of internationalization speed on foreign divestment. Because we also examine moderating effects, we generate interaction terms between the instruments and the moderators, which we then use as instruments in the 2SLS regression models (Wooldridge, 2010).

We use geographic scope (i.e., the number of foreign countries in which a firm operates) and a firm's overall (retail format) market share as instruments in our 2SLS model. Instrumental variables must correlate with the second-stage-dependent variable (foreign divestment) only via their correlation with the first-stage variable (internationalization speed) (Bascle, 2008). Prior research suggests that both firms' geographic scope and their (overall) market share are correlated with internationalization speed (Casillas \& Moreno-Menéndez, 2014; Chang \& Rhee, 2011; Mohr \& Batsakis, 2014), whereas there are no a priori reasons to expect a correlation of these instruments with foreign divestment. In addition, a correlation analysis reveals that both geographic scope and market share significantly correlate with internationalization speed $(r=0.31$ and $r=0.30$, respectively; $p<0.05)$ but not with foreign divestment ( $r=0.07$ and $r=0.02$, respectively; n.s.).

Additionally, instruments should not be related to unobserved variables that partly determine both the independent and dependent variables (Bascle, 2008), e.g., firms' opportunistic or trial-and-error approach to expansion (Penrose, 1959). There are no reasons to expect firms' adoption of such an approach to be per se related to a smaller or larger geographic scope. Likewise, a firm's market share is affected by the behavior and strategies of the firm's competitors in the relevant market segment. We thus suggest that our instruments satisfy this requirement. The absence of any significant correlations between the instruments and the error term of the regression provides empirical confirmation of this suggestion. Additionally, we test for both under- and over-identification and for weak instruments using relevant post-estimation tests (Baum, Schaffer, \& Stillman, 2007). The Anderson canonical correlation likelihood ratio test rejects the null hypothesis $(p=0.000)$ that the model is unidentified. The Cragg-Donald statistic was 15.251 , which is higher than the critical value of 7.77 suggested by Stock and Yogo (2005). We thus reject the null hypothesis for weak instruments. We also performed the Sargan test for over-identifying restrictions (Wooldridge, 2010). The Sargan test yielded insignificant results (Sargan test, $\chi 2=6.591$, $p=0.0861)$, confirming the validity of the selected instruments.

We also use 1-year lags for the independent, moderating and control variables such that a firm's decisions about the level of intra-regional concentration and the decision to divest its foreign operations are treated as sequential decisions, not joint decisions. In addition, we calculate the variance inflation factors (VIFs) to check for potential multicollinearity. The VIFs are below the commonly used threshold value of five, indicating that multicollinearity is not a major issue. However, multicollinearity may emerge from the inclusion of moderating effects in the regression analysis. Therefore, we mean-center the independent and moderating variables before we generate the interaction terms (Aiken \& West, 1991).

Additionally, because we analyze the internationalization activities of foreign firms over a number of years, we include year dummies to account for the possible effects of serial correlation. To control for location-specific unobserved heterogeneity, we include home-region dummies based on Rugman and Verbeke's (2004) broad triad concept. Finally, we include seven industry dummies based on the retail segment in which the retailer has reported its greatest amount of sales (grocery, electrical and office, food service, clothing 
and footwear, leisure and entertainment, health and beauty, home, garden and auto).

\section{RESULTS}

Table 2 provides information about the descriptive statistics and pairwise correlation of the variables. Table 3 presents the results obtained from the 2SLS IV regressions predicting foreign divestment. ${ }^{6}$

Hypothesis 1 predicted a positive relationship between internationalization speed and foreign divestment. The 2SLS regression (Table 3, Model 1) shows positive and statistically significant coefficients $(\beta=0.00385, p<.05)$ for the effect of internationalization speed on foreign divestment. Therefore, our results support Hypothesis 1.

In Hypothesis 2, we suggested a negative moderating effect of intra-regional concentration on the relationship between internationalization speed and foreign divestment. Model 2 in Table 3 shows that the coefficient for the interaction term is negative and statistically significant $(\beta=-0.000219, \quad p<.10)$, thus supporting Hypothesis 2. We plot the interaction graph for the moderating effect of intra-regional concentration on the relationship between internationalization speed and foreign divestment (Figure 1). We use one-half standard deviation above and below the mean value of the moderator to denote high and low levels respectively. ${ }^{7}$ Figure 1 shows that with the exception of very low internationalization speeds, foreign divestment levels are lower for firms with high levels of intra-regional concentration than for firms with low levels of intra-regional concentration. These results reflect the weakening effect of intra-regional concentration on the impact of internationalization speed on foreign divestment, as suggested in Hypothesis 2.

We tested Hypothesis 3, which posited a difference in the relationship between internationalization speed and foreign divestment depending on whether both occur within or outside a firm's home region, by splitting the internationalization speed and foreign divestment variables based on whether they occurred within or outside the firm's home region. The results presented in Table 4 indicate that intra-regional internationalization speed affects a firm's intra-regional foreign divestment ( $\beta=0.00746, p<.01$, Model 3, Table 4) but does not significantly affect foreign divestment outside its home region. In contrast, rapid internationalization outside a firm's home region (i.e., the speed of inter-regional internationalization) does not significantly affect foreign divestment either within or outside a firm's home region. Hypothesis 3 is thus only partially supported.

With regard to Hypothesis 4 and the moderating effect of international experience on the relationship between internationalization speed and foreign divestment, the interaction coefficient is negative and statistically significant ( $\beta=-0.0000311, p<.05)$. Our results thus support hypothesis 4 . Figure 2 illustrates the moderating effect of international experience on the relationship between internationalization speed and foreign divestment. The figure shows that with the exception of very low internationalization speeds, the level of foreign divestment of firms with low levels of international experience surpasses the level of foreign divestment of firms with high internationalization speeds. In contrast, for firms with high levels of international experience, the equivalent increase in foreign divestment is smaller.

We tested Hypotheses $5 \mathrm{a}$ and $5 \mathrm{~b}$, which suggested different effects for international experience depending on whether it is obtained within or outside a firm's home region, by splitting our international experience variable into international experience obtained within a firm's home region and international experience obtained outside a firm's home region (see Table 5).

In line with Hypothesis 5a, our findings show that intra-regional international experience attenuates the effect of intra-regional internationalization speed on intra-regional foreign divestment $(-0.0000945, p<.10$, Model 8, Table 5). Figure 3 illustrates the moderating effect of intra-regional international experience on the relationship between intra-regional internationalization speed and intra-regional foreign divestment. Figure 3 also shows that with the exception of the lowest internationalization speeds, intra-regional foreign divestment levels associated with different intraregional internationalization speeds are higher for firms with low levels of intra-regional experience than for firms with high levels of intra-regional experience. This result in line with Hypothesis 5a, which suggests that intra-regional experience weakens the effect of intra-regional internationalization speed on intra-regional foreign divestment.

In contrast, we find no support for Hypothesis $5 \mathrm{~b}$, which suggested that international experience obtained by operating outside a firm's home region (i.e., inter-regional international experience) attenuates the effect of rapid internationalization 


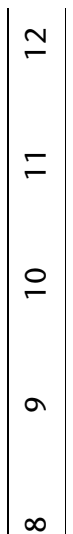

$\infty$

$\wedge$

$\bullet$

in

$\checkmark$

m

$\sim$

$-$

穴$$
\text { to }
$$

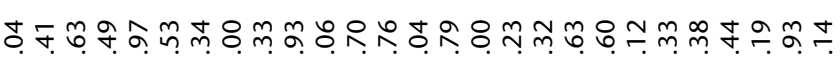

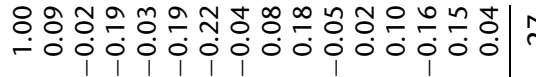

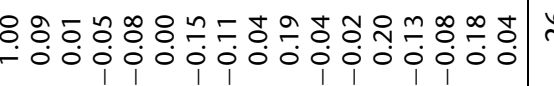

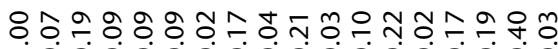
O.

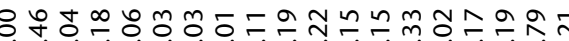

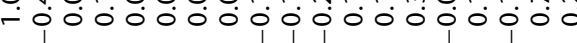

$\stackrel{n}{\stackrel{4}{2}}$

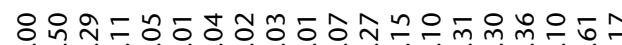

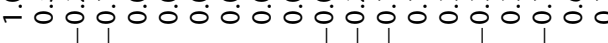

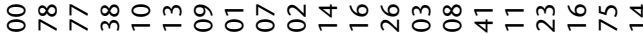

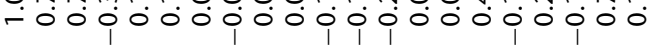

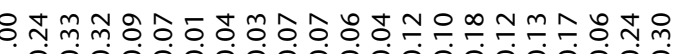
-0000.00000000.0000000

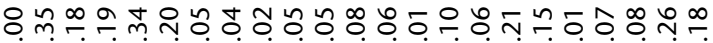

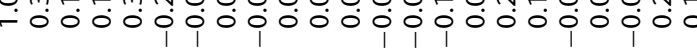

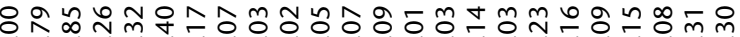
-0000000000000

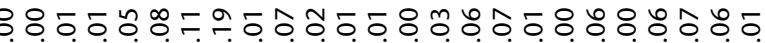
- o. 000000000000000000000

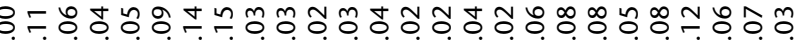

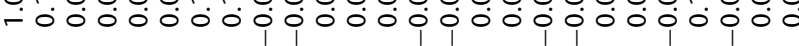

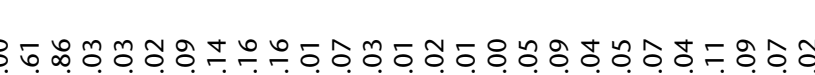

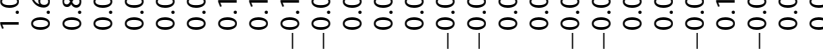

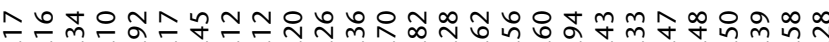

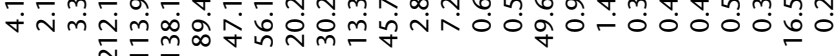
- O म min

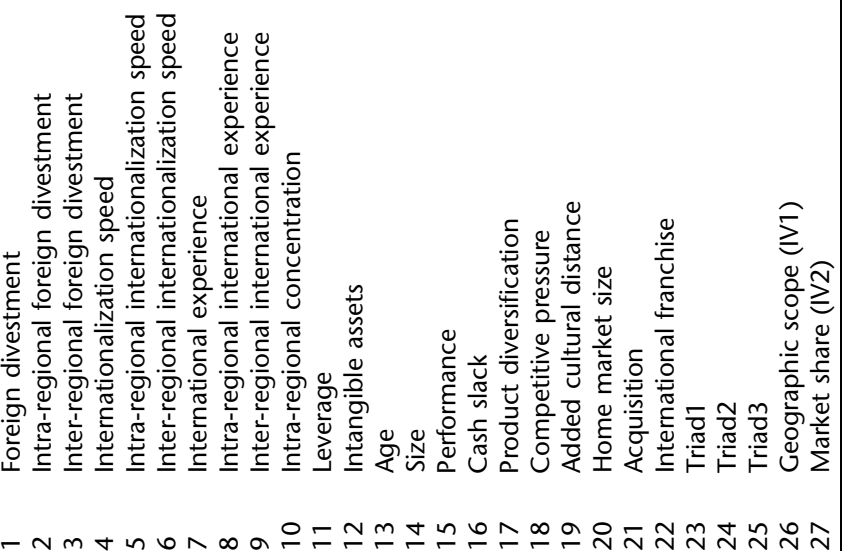

\section{ฟิ \\ $\stackrel{\circ}{\sim}$

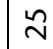 \\ $\stackrel{n}{\sim}$ \\ ก

$\bar{\sim}$ \\ i}

-

$\infty$

=

$\underline{\circ}$

n

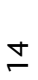

$\stackrel{m}{\sim}$

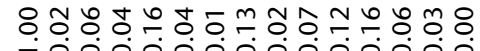

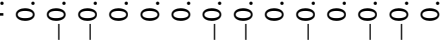

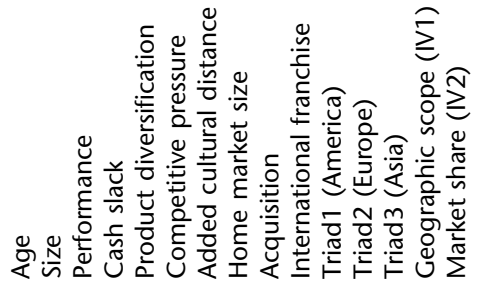

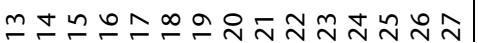


Table 3 2SLS IV regression estimates on foreign divestment

\begin{tabular}{|c|c|c|}
\hline & Model 1 & Model 2 \\
\hline Internationalization speed $(\mathrm{H} 1)$ & $\begin{array}{l}0.00385^{* *} \\
(0.00174)\end{array}$ & $\begin{array}{l}0.00332^{*} \\
(0.00223)\end{array}$ \\
\hline Internationalization speed $\times$ intra-regional concentration $(\mathrm{H} 2)$ & & $\begin{array}{l}-0.000219^{*} \\
(0.000137)\end{array}$ \\
\hline Internationalization speed $\times$ international experience $(\mathrm{H} 4)$ & & $\begin{array}{l}-0.0000311^{\text {** }} \\
(0.0000175)\end{array}$ \\
\hline International experience & $\begin{array}{l}0.00350^{*} \\
(0.00194)\end{array}$ & $\begin{array}{l}0.00837^{\star *} \\
(0.00343)\end{array}$ \\
\hline Intra-regional concentration & $\begin{array}{l}0.000156 \\
(0.00985)\end{array}$ & $\begin{array}{l}0.0237 \\
(0.0169)\end{array}$ \\
\hline Leverage & $\begin{array}{l}-0.000703 \\
(0.0108)\end{array}$ & $\begin{array}{l}-0.00405 \\
(0.0110)\end{array}$ \\
\hline Intangible assets & $\begin{array}{l}0.00771 \\
(0.0127)\end{array}$ & $\begin{array}{l}0.00639 \\
(0.0130)\end{array}$ \\
\hline Age & $\begin{array}{l}0.00172 \\
(0.00332)\end{array}$ & $\begin{array}{l}0.00101 \\
(0.00336)\end{array}$ \\
\hline Size & $\begin{array}{l}0.0811 \\
(0.0590)\end{array}$ & $\begin{array}{l}0.110^{*} \\
(0.0609)\end{array}$ \\
\hline Performance & $\begin{array}{l}-0.00930 \\
(0.0196)\end{array}$ & $\begin{array}{l}-0.00735 \\
(0.0198)\end{array}$ \\
\hline Cash slack & $\begin{array}{l}-0.0708 \\
(0.224)\end{array}$ & $\begin{array}{l}-0.0525 \\
(0.231)\end{array}$ \\
\hline Product diversification & $\begin{array}{l}0.0497 \\
(0.311)\end{array}$ & $\begin{array}{l}0.0314 \\
(0.313)\end{array}$ \\
\hline Competitive pressure & $\begin{array}{l}0.00209 \\
(0.00401)\end{array}$ & $\begin{array}{l}0.00248 \\
(0.00409)\end{array}$ \\
\hline Added cultural distance & $\begin{array}{l}-0.107 \\
(0.149)\end{array}$ & $\begin{array}{l}-0.0957 \\
(0.155)\end{array}$ \\
\hline Home market size & $\begin{array}{l}0.0615 \\
(0.143)\end{array}$ & $\begin{array}{l}0.0243 \\
(0.147)\end{array}$ \\
\hline Acquisition & $\begin{array}{l}-0.117 \\
(0.432)\end{array}$ & $\begin{array}{l}-0.259 \\
(0.428)\end{array}$ \\
\hline International franchise & $\begin{array}{l}-0.334 \\
(0.341)\end{array}$ & $\begin{array}{l}-0.389 \\
(0.351)\end{array}$ \\
\hline Triad 1 (America) & $\begin{array}{l}0.320 \\
(0.495)\end{array}$ & $\begin{array}{l}0.370 \\
(0.506)\end{array}$ \\
\hline Triad 2 (Europe) & $\begin{array}{l}0.708^{*} \\
(0.395)\end{array}$ & $\begin{array}{l}0.710^{*} \\
(0.401)\end{array}$ \\
\hline Constant & $\begin{array}{l}-3.661 \\
(4.207)\end{array}$ & $\begin{array}{l}-2.865 \\
(4.308)\end{array}$ \\
\hline$R^{2}$ & 0.26 & 0.30 \\
\hline Observations & 730 & 730 \\
\hline Number of firms & 120 & 120 \\
\hline
\end{tabular}

Note ${ }^{* * *} p<0.01{ }^{* *} p<0.05{ }^{*} p<0.10$. One-tailed tests are used for hypothesized variables; two-tailed tests are used for controls. Standard errors are in parentheses. All models include year and industry dummies. All models are lagged one year. Instruments used in the 2SLS regression (Model 2): Geographic scope, Geographic scope $\times$ Intra-regional concentration, Geographic scope $\times$ International experience, Market share, Market share $\times$ Intra-regional concentration, and Market share $\times$ International experience. Independent and instrumental variables are mean-centered. Triad 3 (Asia) acts as the reference Triad category.

outside a firm's home region (i.e., inter-regional internationalization speed) on foreign divestment outside its home region (i.e., inter-regional foreign divestment). The relevant coefficient is not statistically significant $(0.0000178$, n.s., Model 10 , Table 5).
We test the sensitivity of our results by rerunning our main analysis using an alternative measure of internationalization speed. Specifically, we measure internationalization speed using the average number of foreign outlets divided by the number of years since the firm's first international expansion 


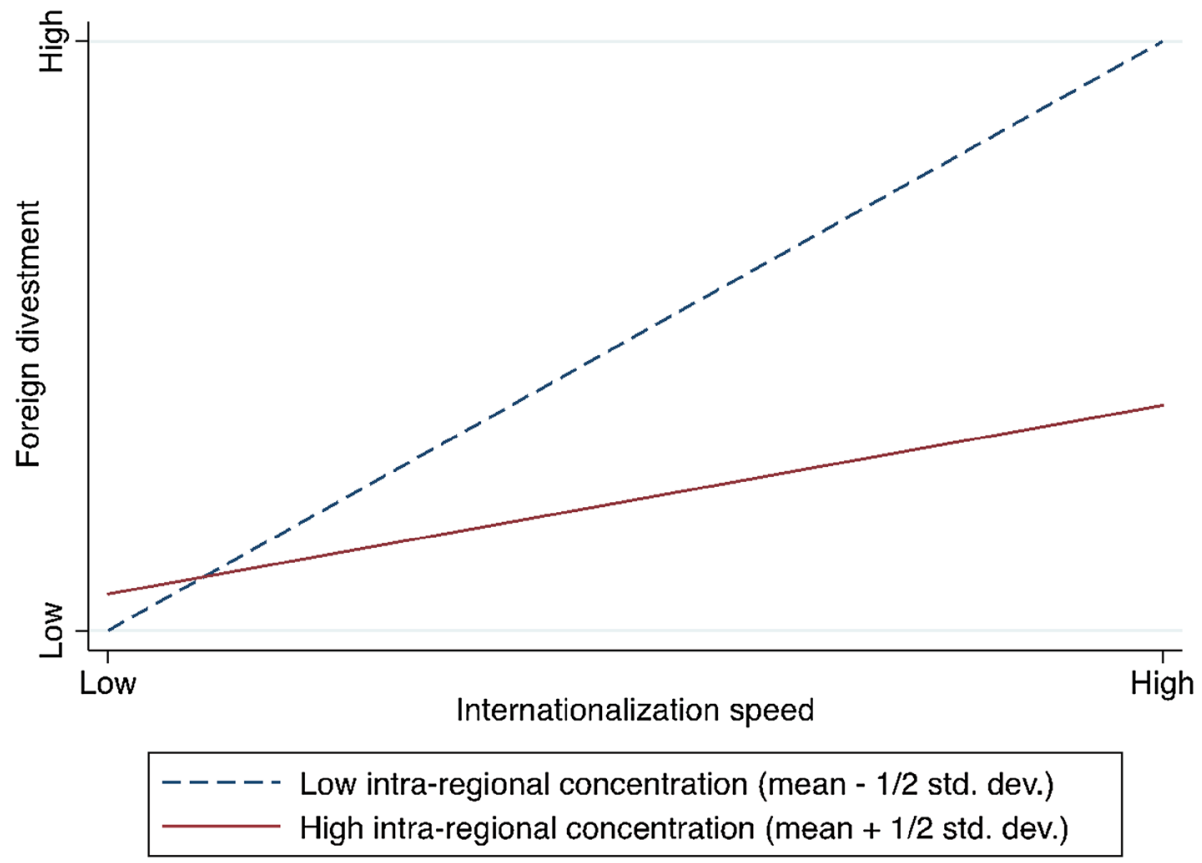

Figure 1 The moderating role of intra-regional concentration on the relationship between internationalization speed and foreign divestment. Note The figure shows foreign divestment levels for different internationalization speeds of firms with high vs. low levels of intra-regional concentration. The plot is based on the regression results of Model 2, Table 3.

(Chang \& Rhee, 2011; Vermeulen \& Barkema, 2002). The results of these additional analyses are consistent with our findings (please see Table A2, Appendix).

Moreover, to eliminate the possibility of a nonlinear relationship between internationalization speed and foreign divestment, we rerun our models with the quadratic term of internationalization speed. The relevant coefficient is not statistically significant; therefore, our result confirms the linear specification. Finally, we re-estimate our main models using a 2-year lag instead of a 1-year lag. The results remain consistent (please see Table A3, Appendix).

\section{DISCUSSION}

This study was motivated by the need for a better understanding of the nature of managerial resources that are central to explanations of (international) firm growth in Penrosean logic. We suggested that studying the effect of rapid international expansion on subsequent foreign divestment would enable us to investigate the role of geographical fungibility as an important characteristic of managerial resources. We frame foreign divestment as an extreme case of the Penrose effect, in which firms attempt to release and redeploy resources following a breach of the Penrosean constraint through rapid international expansion in previous periods. Based on a differentiated view of managerial resources, we expected this effect to be less pronounced both for firms that have expanded internationally primarily within their home region and for firms that have high levels of international experience.

We argued and found empirical support for a positive effect of internationalization speed on subsequent overseas divestment. Our argument based in Penrosean logic suggested that excessive strain on firms' managerial resources resulting from rapid internationalization would lead to difficulties in planning, coordination and learning from overseas expansion. We proposed that divestment allows the release of managerial resources to eliminate or ease the negative effects of excessive strain on firms' managerial resources. Because of the possibility that difficulties in planning, coordinating and learning from overseas expansion lead to foreign divestment by affecting firm performance, we explored whether firm performance played such a mediating role using the three-step approach suggested by Baron and Kenny (1986). ${ }^{8}$ The results of this analysis showed that performance does not mediate the relationship between rapid internationalization and foreign divestment. This result is 
Table 4 2SLS IV regression estimates for the effects of intra-/inter-regional internationalization speed on intra-/inter-regional foreign divestment

\begin{tabular}{|c|c|c|c|c|}
\hline & Intra-region & n divestment & Inter-regio & gn divestment \\
\hline & Model 3 & Model 4 & Model 5 & Model 6 \\
\hline Intra-regional internationalization speed $(\mathrm{H} 3)$ & $\begin{array}{l}0.00746^{* * *} \\
(0.00307)\end{array}$ & & $\begin{array}{l}0.00434 \\
(0.00259)\end{array}$ & \\
\hline Inter-regional internationalization speed $(\mathrm{H} 3)$ & & $\begin{array}{l}0.00323 \\
(0.00189)\end{array}$ & & $\begin{array}{l}0.00170 \\
(0.00165)\end{array}$ \\
\hline International experience & $\begin{array}{l}0.00220 \\
(0.00134)\end{array}$ & $\begin{array}{l}0.00167 \\
(0.00136)\end{array}$ & $\begin{array}{l}0.00196^{*} \\
(0.00113)\end{array}$ & $\begin{array}{l}0.00171 \\
(0.00118)\end{array}$ \\
\hline Intra-regional concentration & $\begin{array}{l}0.0104 \\
(0.00779)\end{array}$ & $\begin{array}{l}0.00241 \\
(0.00634)\end{array}$ & $\begin{array}{l}-0.00201 \\
(0.00657)\end{array}$ & $\begin{array}{l}-0.00681 \\
(0.00554)\end{array}$ \\
\hline Leverage & $\begin{array}{l}0.00126 \\
(0.00770)\end{array}$ & $\begin{array}{l}-0.000318 \\
(0.00731)\end{array}$ & $\begin{array}{l}-0.000395 \\
(0.00653)\end{array}$ & $\begin{array}{l}-0.00141 \\
(0.00638)\end{array}$ \\
\hline Intangible assets & $\begin{array}{l}0.00560 \\
(0.00908)\end{array}$ & $\begin{array}{l}0.00839 \\
(0.00856)\end{array}$ & $\begin{array}{l}-0.000740 \\
(0.00768)\end{array}$ & $\begin{array}{l}0.000866 \\
(0.00747)\end{array}$ \\
\hline Age & $\begin{array}{l}-3.87 e-05 \\
(0.00236)\end{array}$ & $\begin{array}{l}0.000119 \\
(0.00225)\end{array}$ & $\begin{array}{l}0.00155 \\
(0.00199)\end{array}$ & $\begin{array}{l}0.00164 \\
(0.00197)\end{array}$ \\
\hline Size & $\begin{array}{l}0.0419 \\
(0.0419)\end{array}$ & $\begin{array}{l}0.0431 \\
(0.0400)\end{array}$ & $\begin{array}{l}0.0373 \\
(0.0354)\end{array}$ & $\begin{array}{l}0.0378 \\
(0.0349)\end{array}$ \\
\hline Performance & $\begin{array}{l}-0.0109 \\
(0.0139)\end{array}$ & $\begin{array}{l}-0.00601 \\
(0.0131)\end{array}$ & $\begin{array}{l}-0.00295 \\
(0.0119)\end{array}$ & $\begin{array}{l}0.000218 \\
(0.0115)\end{array}$ \\
\hline Cash slack & $\begin{array}{l}-0.128 \\
(0.160)\end{array}$ & $\begin{array}{l}-0.0856 \\
(0.151)\end{array}$ & $\begin{array}{l}0.0190 \\
(0.135)\end{array}$ & $\begin{array}{l}0.0467 \\
(0.132)\end{array}$ \\
\hline Product diversity & $\begin{array}{l}0.0495 \\
(0.221)\end{array}$ & $\begin{array}{l}0.0116 \\
(0.212)\end{array}$ & $\begin{array}{l}0.0472 \\
(0.186)\end{array}$ & $\begin{array}{l}0.0260 \\
(0.185)\end{array}$ \\
\hline Competitive pressure & $\begin{array}{l}0.00253 \\
(0.00289)\end{array}$ & $\begin{array}{l}0.00146 \\
(0.00269)\end{array}$ & $\begin{array}{l}0.000625 \\
(0.00245)\end{array}$ & $\begin{array}{l}-0.000709 \\
(0.00235)\end{array}$ \\
\hline Added cultural distance & $\begin{array}{l}-0.0260 \\
(0.106)\end{array}$ & $\begin{array}{l}-0.0459 \\
(0.101)\end{array}$ & $\begin{array}{l}-0.0640 \\
(0.0895)\end{array}$ & $\begin{array}{l}-0.0751 \\
(0.0879)\end{array}$ \\
\hline Home market size & $\begin{array}{l}-0.0657 \\
(0.105)\end{array}$ & $\begin{array}{l}0.0274 \\
(0.0977)\end{array}$ & $\begin{array}{l}0.0249 \\
(0.0888)\end{array}$ & $\begin{array}{l}0.0771 \\
(0.0853)\end{array}$ \\
\hline Acquisition & $\begin{array}{l}-0.0244 \\
(0.316)\end{array}$ & $\begin{array}{l}0.197 \\
(0.282)\end{array}$ & $\begin{array}{l}-0.304 \\
(0.272)\end{array}$ & $\begin{array}{l}-0.162 \\
(0.247)\end{array}$ \\
\hline International franchise & $\begin{array}{l}-0.182 \\
(0.242)\end{array}$ & $\begin{array}{l}-0.215 \\
(0.231)\end{array}$ & $\begin{array}{l}-0.112 \\
(0.205)\end{array}$ & $\begin{array}{l}-0.128 \\
(0.202)\end{array}$ \\
\hline Triad 1 (America) & $\begin{array}{l}0.0998 \\
(0.350)\end{array}$ & $\begin{array}{l}0.0552 \\
(0.337)\end{array}$ & $\begin{array}{l}0.279 \\
(0.295)\end{array}$ & $\begin{array}{l}0.261 \\
(0.294)\end{array}$ \\
\hline Triad 2 (Europe) & $\begin{array}{l}0.524^{*} \\
(0.282)\end{array}$ & $\begin{array}{l}0.573^{* *} \\
(0.267)\end{array}$ & $\begin{array}{l}0.141 \\
(0.238)\end{array}$ & $\begin{array}{l}0.173 \\
(0.233)\end{array}$ \\
\hline Constant & $\begin{array}{l}0.757 \\
(3.088)\end{array}$ & $\begin{array}{l}-1.978 \\
(2.898)\end{array}$ & $\begin{array}{l}-1.392 \\
(2.607)\end{array}$ & $\begin{array}{l}-2.918 \\
(2.531)\end{array}$ \\
\hline$R^{2}$ & 0.16 & 0.26 & 0.21 & 0.18 \\
\hline Observations & 730 & 730 & 730 & 730 \\
\hline Number of firms & 120 & 120 & 120 & 120 \\
\hline
\end{tabular}

${ }^{* * *} p<0.01,{ }^{* *} p<0.05{ }^{*} p<0.10$. One-tailed tests are used for hypothesized variables; two-tailed tests are used for controls. Standard errors are in parentheses. All models include year and industry dummies. All models are lagged 1 year. Instruments used in the 2SLS regression: Geographic scope and Market share. Independent and instrumental variables are mean-centered. Triad 3 (Asia) acts as the reference Triad category.

in line with our suggestion that managers can make decisions about foreign divestment once they have information about the constraints on managerial resources (and the negative consequences) associated with rapid internationalization, regardless of whether these constraints have already led to negative effects on firm performance. However, given the role that a lack of performance has traditionally played in research on divestment, future research that disentangles the relationships of these variables seems warranted. 


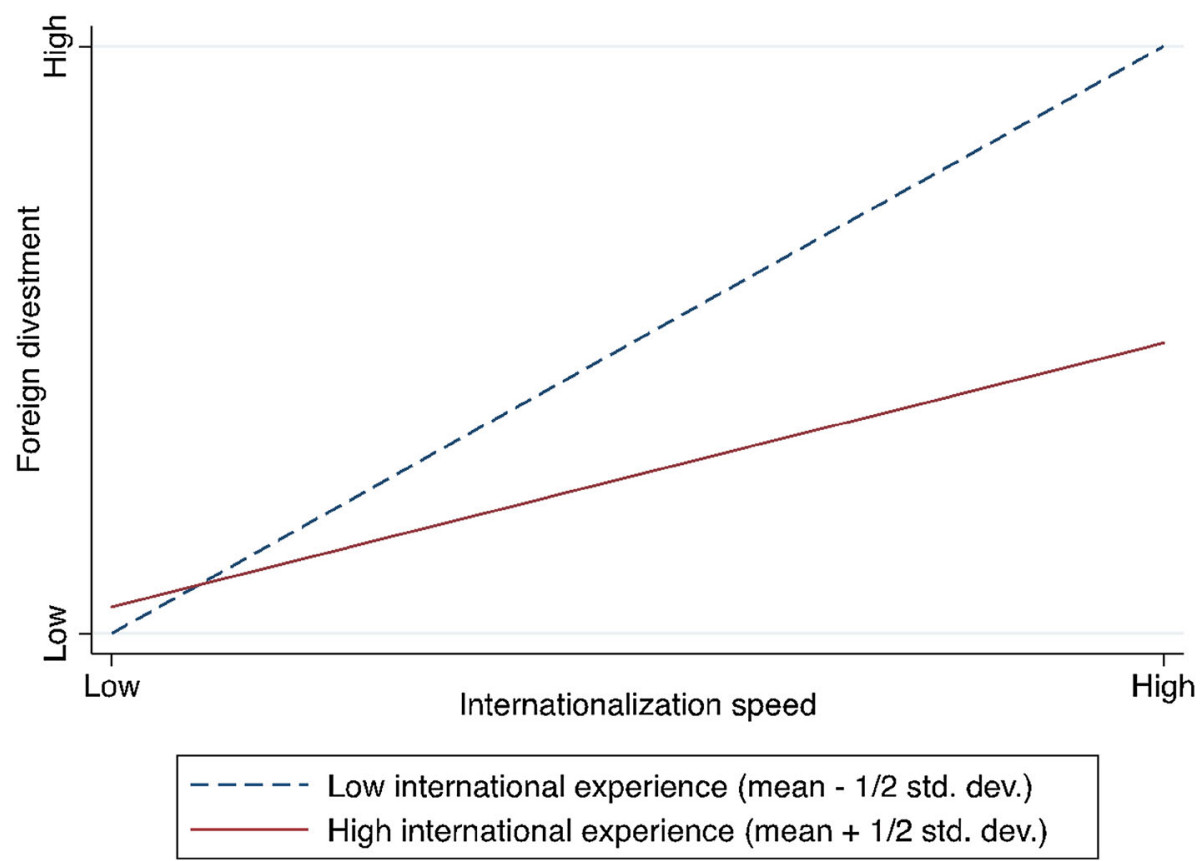

Figure 2 The moderating role of international experience on the relationship between internationalization speed and foreign divestment. Note The figure shows foreign divestment levels for different internationalization speeds of firms with high vs. low levels of international experience. The plot is based on the regression results of Model 2, Table 3.

\section{Geographic Patterns of International Expansion and Divestment}

We argued and found that the effect of internationalization speed on foreign divestment is weaker for firms that expand predominantly within their home region. Our findings thus support the logic underlying regional strategy with respect to the greater difficulties associated with inter-regional expansion than intra-regional expansion (Rugman \& Verbeke, 2004). Although past research suggests that firms may be reluctant to expand interregionally in the first place, our findings imply that firms may revert to intra-regional strategies after expanding and withdrawing from markets outside of their home region. Therefore, we contribute to the development of regional strategy theory (Rugman \& Verbeke, 2004, 2005) by testing its logic in the divestment context and investigating the indirect effect instead of the direct effect of intraregional concentration on foreign divestment.

Based on the likely limitations of cross-regional fungibility of managerial resources, we further hypothesized that the relationship between internationalization speed and subsequent foreign divestment will depend on whether they both occur within or outside the firm's home region. In line with Hypothesis 3, our results show that rapid internationalization within a firm's home region positively affects foreign divestment within but not outside this region. Our results also show that rapid internationalization outside a firm's home region positively affects divestment both within and outside the firm's home region. Because we expected no effect of rapid internationalization outside a firm's home region on foreign divestment within the firm's home region, there is only partial support for Hypothesis 3. One possible explanation for this finding may be that the managerial resources involved in international operations within a firm's home region may be (or may be regarded by firms as) more fungible than managerial resources involved in international operations outside a firm's home region. Thus, managerial resources involved in international operations within a firm's home region might be more likely to be released in order to ease the strain associated with both intraand inter-regional international expansion. The skills and services provided by managerial resources involved in operations in the firm's home region may be (or may be seen as being) transferable to international operations both within and outside of the firm's home region. Accordingly, there may be variations in the actual or perceived limitations of cross-regional transferability of managerial resources and services, reflecting the different degrees to which firm-specific advantages are 
Table 5 2SLS IV regression estimates for the moderating effect of different types of experience

\begin{tabular}{|c|c|c|c|c|}
\hline & \multicolumn{2}{|c|}{ Intra-regional foreign divestment } & \multicolumn{2}{|c|}{ Inter-regional foreign divestment } \\
\hline & Model 7 & Model 8 & Model 9 & Model 10 \\
\hline \multirow{2}{*}{ Intra-regional internationalization speed } & $0.00762^{* *}$ & $0.0190 * *$ & & \\
\hline & $(0.00382)$ & $(0.00922)$ & & \\
\hline \multirow[t]{2}{*}{ Intra-regional international experience } & 0.00401 & $0.00723^{*}$ & & \\
\hline & $(0.00253)$ & $(0.00410)$ & & \\
\hline \multirow{2}{*}{$\begin{array}{l}\text { Intra-regional internationalization speed } \times \text { intra-regional } \\
\text { international experience }(\mathrm{H} 5 \mathrm{a})\end{array}$} & & $-0.0000945^{\star}$ & & \\
\hline & & $(0.0000647)$ & & \\
\hline \multirow[t]{2}{*}{ Inter-regional internationalization speed } & & & $9.28 \mathrm{e}-06$ & 0.000746 \\
\hline & & & $(0.00204)$ & $(0.00224)$ \\
\hline \multirow[t]{2}{*}{ Inter-regional international experience } & & & $0.00483^{* *}$ & -0.000207 \\
\hline & & & $(0.00227)$ & $(0.00285)$ \\
\hline \multirow{2}{*}{$\begin{array}{l}\text { Inter-regional internationalization speed } \times \text { inter-regional } \\
\text { international experience }(\mathrm{H} 5 \mathrm{~b})\end{array}$} & & & & 0.0000178 \\
\hline & & & & $(0.0000111)$ \\
\hline \multirow[t]{2}{*}{ Intra-regional concentration } & 0.00938 & 0.0179 & -0.00586 & -0.00706 \\
\hline & $(0.00846)$ & $(0.0133)$ & $(0.00547)$ & $(0.00579)$ \\
\hline \multirow[t]{2}{*}{ Leverage } & 0.00261 & 0.00421 & -0.00295 & -0.000890 \\
\hline & $(0.00802)$ & $(0.0108)$ & $(0.00638)$ & $(0.00661)$ \\
\hline \multirow[t]{2}{*}{ Intangible assets } & 0.00631 & -0.00285 & 0.000872 & 0.00126 \\
\hline & $(0.00949)$ & $(0.0141)$ & $(0.00739)$ & $(0.00768)$ \\
\hline \multirow[t]{2}{*}{ Age } & 0.000427 & 0.000149 & 0.00170 & 0.00168 \\
\hline & $(0.00248)$ & $(0.00353)$ & $(0.00195)$ & $(0.00202)$ \\
\hline \multirow[t]{2}{*}{ Size } & 0.0438 & 0.0577 & 0.0362 & 0.0284 \\
\hline & $(0.0438)$ & $(0.0623)$ & $(0.0346)$ & $(0.0367)$ \\
\hline \multirow[t]{2}{*}{ Performance } & -0.0108 & -0.0172 & 0.00204 & 0.00191 \\
\hline & $(0.0143)$ & $(0.0173)$ & $(0.0114)$ & $(0.0120)$ \\
\hline \multirow[t]{2}{*}{ Cash slack } & -0.138 & -0.238 & 0.0840 & 0.0764 \\
\hline & $(0.168)$ & $(0.238)$ & $(0.133)$ & $(0.140)$ \\
\hline \multirow[t]{2}{*}{ Product diversity } & 0.0364 & -0.0221 & 0.0452 & 0.0452 \\
\hline & $(0.232)$ & $(0.333)$ & $(0.184)$ & $(0.192)$ \\
\hline \multirow[t]{2}{*}{ Competitive pressure } & 0.00252 & 0.00156 & -0.000254 & -0.000213 \\
\hline & $(0.00301)$ & $(0.00406)$ & $(0.00231)$ & $(0.00240)$ \\
\hline \multirow[t]{2}{*}{ Added cultural distance } & -0.00771 & 0.125 & -0.0791 & -0.0915 \\
\hline & $(0.110)$ & $(0.156)$ & $(0.0867)$ & $(0.0916)$ \\
\hline \multirow[t]{2}{*}{ Home market size } & -0.0644 & -0.143 & 0.0284 & 0.0417 \\
\hline & $(0.112)$ & $(0.165)$ & $(0.0886)$ & $(0.0920)$ \\
\hline \multirow[t]{2}{*}{ Acquisition } & -0.0350 & -0.181 & -0.132 & -0.263 \\
\hline & $(0.330)$ & $(0.374)$ & $(0.246)$ & $(0.250)$ \\
\hline \multirow{2}{*}{ International franchise } & -0.151 & -0.174 & -0.108 & -0.00202 \\
\hline & $(0.247)$ & $(0.356)$ & $(0.192)$ & $(0.214)$ \\
\hline \multirow[t]{2}{*}{ Triad 1 (America) } & 0.118 & 0.0535 & 0.310 & 0.302 \\
\hline & $(0.368)$ & $(0.536)$ & $(0.294)$ & $(0.307)$ \\
\hline Triad 2 (Europe) & $0.507^{*}$ & 0.430 & 0.191 & 0.171 \\
\hline & $(0.297)$ & $(0.427)$ & $(0.231)$ & $(0.239)$ \\
\hline Constant & 0.478 & 2.522 & -1.541 & -1.879 \\
\hline & (3.287) & $(4.773)$ & $(2.633)$ & $(2.745)$ \\
\hline$R^{2}$ & 0.15 & 0.16 & 0.18 & 0.21 \\
\hline Observations & 730 & 730 & 730 & 730 \\
\hline Number of firms & 120 & 120 & 120 & 120 \\
\hline
\end{tabular}

${ }^{* * *} p<0.01,{ }^{* *} p<0.05,{ }^{*} p<0.10$. One-tailed tests are used for hypothesized variables; two-tailed tests are used for controls. Standard errors are in parentheses. All models include year and industry dummies. All models are lagged one year. Instruments used in the 2SLS regression (Models $8 \& 10$ ): Geographic scope, Geographic scope $\times$ International experience, Market share, and Market share $\times$ International experience. Independent and instrumental variables are mean-centered. Triad 3 (Asia) acts as the reference Triad category. 


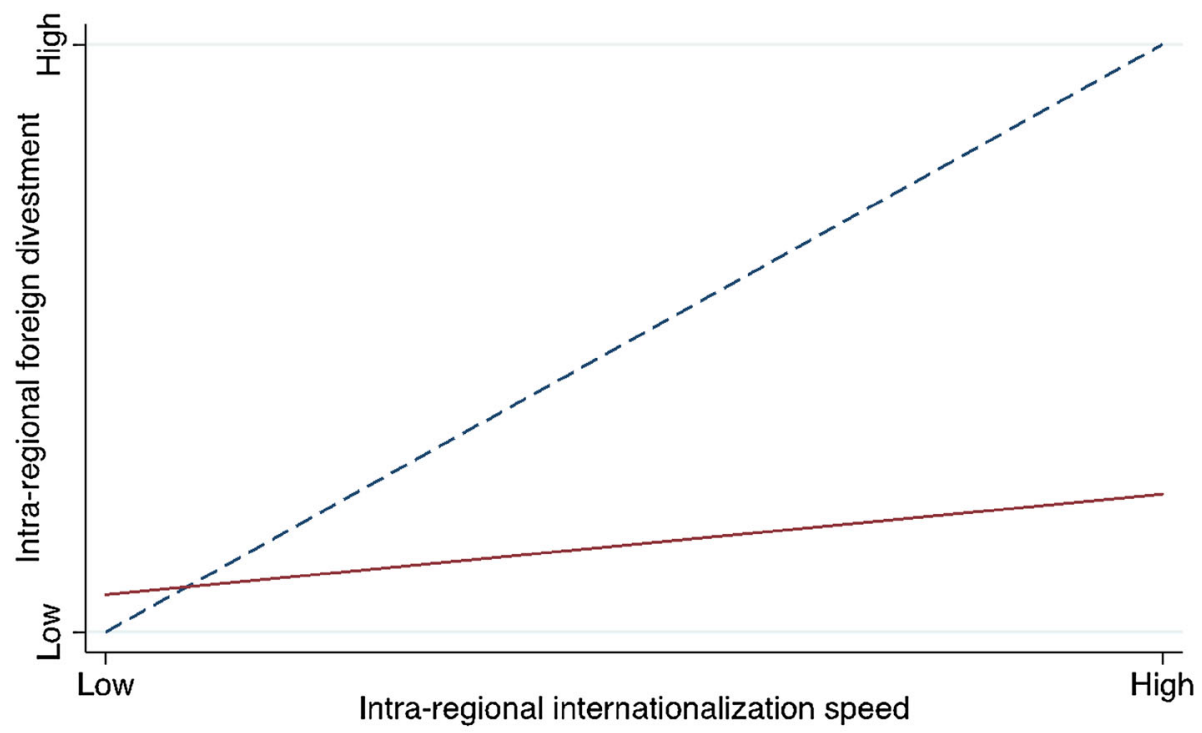

$----\cdot$ Low intra-regional international experience (mean - 1/2 std. dev.)
High intra-regional international experience (mean $+1 / 2$ std. dev.)

Figure 3 The moderating role of intra-regional international experience on the relationship between intra-regional internationalization speed and intra-regional foreign divestment. Note The figure shows intra-regional foreign divestment levels for different intra-regional internationalization speeds of firms with high vs. low levels of intra-regional international experience. The plot is based on the regression results of Model 8, Table 5.

transferable across regions, as explained in regional strategy theory (Oh \& Rugman, 2012; Verbeke \& Asmussen, 2016). Additionally, our finding underlines the need to differentiate both managerial resources and the productive services these resources can provide when applying Penrosean logic in the context of firm internationalization. For example, we suggest that the limits on the international or inter-regional fungibility of managerial resources and their services should play a more central role in what Håkanson and Kappen (2017) have called the 'Casino Model' of internationalization. These authors explain this "less restrained" type of internationalization with an assumed significant decline in the marginal cost of further international growth "[o]nce the fixed costs of developing, or acquiring, the managerial capacity and organizational routines necessary to expand internationally have been incurred." We suggest that limits on the fungibility of managerial resources may weaken this assumed decline in marginal cost. In general, our findings support the central insight of regional strategy theory, that is, firms' resource bundles are better exploited within as opposed to outside their home regions because of the greater similarity of countries within as opposed to across regions and the associated inter- regional liability of foreignness (Rugman \& Verbeke, 2005, 2007).

Our results for Hypothesis 3 also provide complementary explanations for the findings of studies that investigate the effects of foreign divestment on subsequent internationalization based on the assumed release and subsequent reallocation of firm resources that would occur in such cases (Arregle, Beamish, \& Hébert, 2009; Chan, Makino, \& Isobe, 2006). Arregle, Beamish, and Hébert (2009) find that firms use the resources released by divesting subsidiaries to invest in other countries in the same region as the divested subsidiaries, explaining this finding in terms of firms' desire to exploit intra-regional arbitrage opportunities. Arregle, Beamish, and Hébert (2009) do not mention the limited inter-regional fungibility of managerial resources and of the services that these resources can provide. However, our findings suggest that such limitations may mean that resources released through the divestment of subsidiaries might not be transferrable to operations outside the region of the divested subsidiaries, regardless of any arbitrage opportunities. Similarly, Chan, Makino, and Isobe (2006, p. 647) suggest that the foreign entry decisions of Japanese firms are affected by their prior foreign exits because such exits enable them 
to "redeploy the released internal resources to support subsequent entries into new markets." The authors also argue that too many exits may signal that the firm's stakeholders do not support the firm's overseas operations. Chan, Makino, and Isobe (2006) find only limited support for the associated inverted U-shaped relationship between prior exits and subsequent entries and explain this result by suggesting that the interdependence among a firm's overseas operations might not play an important role in firms' international expansion. Our results and analyses suggest that if the authors had accounted for the geographic locations of both foreign exits and subsequent foreign entries, they would have found evidence of such interdependence.

Although we are interested in the relationship between the regional pattern of internationalization speed and the regional pattern of foreign divestment, our arguments might also apply to firms' domestic divestment because domestic divestment can also release managerial resources. Although focused on US manufacturing firms, Berry (2010) argues that foreign expansion may lead to the divestment of firms' domestic operations because of constraints on firms' resources and resource trade-offs. We therefore also tested the effect of rapid internationalization speed on retailers' divestment of home-country operations. ${ }^{9}$ The results of this analysis do not indicate any significant effects. From a Penrosean perspective, these findings therefore indicate that firms do not react with a release of managerial resources through domestic divestment when confronted by the resource strains associated with rapid international expansion. This finding suggests that firms' managerial resources and the services that such resources provide may suffer not only from limited inter-regional fungibility but also from limited international fungibility, which underscores the need to account for this issue when employing Penrosean logic in the context of firm (de)internationalization. Managing overseas operations requires managers with specific skills and abilities (e.g., Mendenhall, Dunbar, \& Oddou, 1987), and firms may be more likely to divest overseas operations to release existing managerial resources from international positions (not domestic positions) of the firm. Our finding also contrasts with Berry's (2010) suggestion that the resource-transfer logic applies to both home country subsidiaries and overseas subsidiaries. An alternative explanation for this finding may lie in the fact that firms are generally more likely to divest foreign operations than domestic operations. This tendency may be due to lower foreign barriers to exit - for example, managers may have lower emotional attachments to overseas operations than to domestic operations (see, for instance, Boddewyn, 1983a, 1983b) - or to the trial-and-error approach to international expansion, which is associated with a greater readiness to divest overseas operations (e.g., Mariotti \& Piscitello, 1999).

\section{The Moderating Role of International Experience} Our fourth hypothesis proposed a moderating effect of firms' international experience. Prior research has argued for the direct effect of international experience on a firm's foreign divestment (e.g., Barkema, Bell, \& Pennings, 1996; Benito, 1997). In contrast, we draw on Penrosean logic to argue that international experience moderates the effects of rapid internationalization on subsequent foreign divestment. International experience increases the services that a firm's managerial resources can provide (Penrose, 1959) and thus mitigates the increased strain associated with rapid internationalization. Therefore, we expected international experience to weaken the direct effect of internationalization speed on foreign divestment. The empirical support for this effect confirms the importance of experiential learning through international experience in the context of firm internationalization (Clarke, Tamaschke, \& Liesch, 2013). It also extends this research by highlighting the moderating effect of international experience in the context of foreign divestment.

In Hypotheses $5 \mathrm{a}$ and $5 \mathrm{~b}$, we argued that the suggested moderating effect of international experience on the relationship between rapid internationalization and foreign divestment would vary depending on the type of international experience, i.e., whether the international experience was obtained within or outside the firm's home region. We find that home-region experience attenuates the effect of home-region internationalization speed on foreign divestment in a firm's home region. In contrast, experience obtained from operating outside a firm's home region does not attenuate the effect of rapid internationalization outside a firm's home region on its foreign divestments outside its home region. One possible explanation for this result may be that expansion outside the home region captures a larger and more heterogeneous set of countries and conditions; thus, the international experience obtained 
through such operations may be heterogeneous and bound to particular regions. For example, although a US retailer's experience of operating stores in Europe may help to reduce the negative effects of rapid internationalization in Europe, this experience may be less useful in reducing the negative effects of rapid internationalization in Asia. We distinguished only between international experience obtained within a firm's home region and international experience obtained outside the home region. Future research should use more finely grained classifications. Finally, our findings provide some support for the suggestion that international experience is region-bounded (Oh, Sohl, \& Rugman, 2015). According to Asmussen (2012, p. 277), international experience may be fungible within but not across regions and may increase "the attractiveness of further investment in a region where sunk investments have already been incurred." This assessment is in line with our finding that for firms with high levels of intraregional international experience, the effect of home-region internationalization speed on foreign divestment in a firm's home region is weaker than for firms with low levels of intra-regional international experience.

\section{CONCLUSIONS}

Overall, our arguments based on Penrose (1959) and the results of our empirical study contribute to the development of the Penrosean perspective and its application in the international business context (Hutzschenreuter, Voll, \& Verbeke, 2011; Tan \& Mahoney, 2005; Verbeke \& Yuan, 2007). Specifically, we provide a first attempt at "unpacking" Penrosean managerial resources by theorizing about the variation in the geographical fungibility of different types of managerial resources. By studying the effect of rapid international growth on subsequent foreign divestment, we extend the Penrose effect to include an explanation of how managerial resource constraints may lead not only to a slow-down or pause in firms' international expansion (Hutzschenreuter, Voll, \& Verbeke, 2011) but also to the divestment of foreign operations. We contribute to the development of Penrosean logic by discussing and clarifying the assumptions that underlie its application in existing research on product diversification (Helfat \& Eisenhardt, 2004; Levinthal \& Wu, 2010; Roberts \& McEvily, 2005) in the context of foreign divestment in the retail sector. These assumptions relate both to the degree to which managerial resources can be "freed up" through the divestment of product lines/foreign operations and the length of time between the release of these resources and their availability for alternative uses within the firm.

By integrating insights from regional strategy theory to clarify certain boundary conditions of Penrosean logic in the context of international firm growth, we also respond to calls for a rethinking of existing theories on the basis of regional strategy theory (Verbeke \& Asmussen, 2016). Our analyses and findings suggest that differences between regions affect both the services required and the services provided by the managerial resources of firms that operate across geographic regions. We suggest that these differences go beyond the "subsidiary "empirical' assumptions" that Penrose (1995: xv) argues are required when transferring her arguments to the context of internationally operating firms. Future research on (de)internationalization that builds on Penrose's insights should therefore clarify how different (de)internationalization patterns place strain on and create interdependencies among different types of managerial resources.

Finally, our study contributes to overcoming the relative dearth of theoretical explanations for (international) divestment (Agarwal, Audretsch, \& Sarkar, 2007; Boddewyn, 1983a, 1983b; Mahoney \& Pandian, 1992). Although recent research has made progress in developing theoretical explanations of overseas divestment (e.g., Belderbos \& Zou, 2009; Soule, Swaminathan, \& Tihanyi, 2014; Wan, Chen, \& Yiu, 2015), we suggest that such explanations need to account for firms' managerial resources, which are limited and may not be fungible across geographic regions.

\section{Managerial Implications}

Our study has a number of managerial implications. First, managers are advised to pay more attention to the speed of firm internationalization and the possible effects of failing to spend time on planning, integrating and learning from overseas operations. We have argued that rapid internationalization exerts a strain not only on the managers involved in a particular expansion but also on the managers of existing international operations. Although the possibility of foreign divestment has been connected to several firm-, subsidiary- and country-level factors (for an overview, see Morschett, Donath, Swoboda, \& Schramm-Klein, 2011), our study highlights the speed of 
internationalization and its effects on firms' managerial resources. Failing to account for these issues may heighten the risk of foreign divestments.

Our findings also suggest that some firms are better than others at mitigating the negative effects of rapid internationalization and thus face a lower risk that overseas operations will need to be divested due to rapid internationalization. Specifically, our results show that compared with interregional expansion, intra-regional expansion results in less strain associated with rapid international expansion. Our analysis also indicates that the managerial resources needed to manage international operations have limited fungibility across regions. Firms thus need to be aware of issues beyond the region-boundedness of firm-specific advantages, because region-boundedness might also limit the transfer of a wider range of resources within internationally operating firms. If firms engaged in internationalization are relying on the inter-regional transfer of managerial resources and their services, they must carefully assess whether their managers" "regional mindsets" or regio-centric orientations (Hennan \& Perlmutter, 1979) can be transformed into "global mindsets" (Levy, Beechler, Taylor, \& Boyacigiller, 2007).

We also find evidence that internationally experienced firms face fewer disadvantages from rapid internationalization and therefore are less likely to divest their foreign operations. Therefore, it seems advisable to obtain international experience prior to engaging in fast-paced international expansion. Distinguishing between the experiences of operating within and outside a firm's home region also shows that the former (latter) helps to ease the resource strain associated with rapid internationalization within (outside) a firm's home region. Therefore, firms should recognize the potential region-boundedness of their managers' international experiences and the potentially limited relevance of these experiences for internationalization patterns that takes the managers outside the home region.

\section{Limitations}

Our study has several limitations. Our aim was to develop a parsimonious model of divestment based on Penrose (1959). Although we control for potential alternative explanations for divestment in our empirical analysis, other factors are likely to affect a firm's decision to divest overseas operations. Prior research has argued that changes in host-country attractiveness (Benito \& Welch, 1997; Berry, 2013), policy instability in the host country (Berry, 2013), and pronounced differences between the host and home countries (Pattnaik \& Lee, 2014) increase the likelihood of divesting from foreign operations. Although we control for the range of GDP per capita of the countries into which a firm has expanded, future research may be able to use more finely grained measures of the attractiveness of different host countries.

Additionally, our study analyzes firms' horizontal expansion and (subsequent) horizontal divestment given the relevance of the transfer and crowding out of managerial resources between different parts of firms' (horizontal) operations. Because of the comparatively low importance of such transfers in vertical expansion situations, Penrose's analysis may be less applicable to vertical expansion (Kay, 1999) and thus to vertical divestment. Explaining vertical divestment therefore might require us to complement Penrose's logic with insights from other theories, particularly transaction cost economics. This seems a worthwhile extension of our study, especially given the indications that (overseas) subsidiaries are more likely to be divested if they are unrelated to the product/services of the parent firm (Berry, 2013; Chang \& Singh, 1999). Finally, we did not account for different types of divestment (Alexander, Quinn, \& Cairns, 2005; Hennart, Kim, \& Zeng, 1998; Jackson, Mellahi, \& Sparks, 2005) because our basic argument applies to all types of exit. ${ }^{10}$ We suggest that all types of divestment allow for the release of managerial resources that can be redeployed to ease constraints on these resources associated with overly rapid international expansion. However, the degree and speed of resource release is likely to vary with the type of divestment; thus, different types of divestment are likely to vary in terms of their ability to release managerial resources. Divestments may relate to individual foreign outlets or the entire operations in one or more overseas markets and may occur through liquidation or the sale of operations to another party, potentially even to an actual or potential competitor. One would expect a faster release of managerial resources in the case of liquidation of an individual outlet in an overseas market than in the case of divestment of ongoing operations in multiple countries to a competitor. Because we do not have information about the type of divestment in our sample, we cannot explore this possibility empirically.

By theorizing about the nature and fungibility of Penrosean managerial resources in the context of 
rapid internationalization and their effect on subsequent foreign divestment, we contribute to a better understanding of these managerial resources for firm (de-)internationalization. We believe there is a need for future research to provide finer-grained analyses of Penrosean managerial resources and their effects on different dimensions of firm internationalization.

\section{ACKNOWLEDGEMENTS}

We would like to thank Area Editor Peter Liesch and two anonymous reviewers for their valuable insights and comments. We are also grateful to Andreas Georgiadis, Niron Hashai, Palitha Konara, Philip Nell, and Chengang Wang for their feedback on earlier drafts of this manuscript.

\section{NOTES}

${ }^{1}$ Although Penrose does not discuss divestment as a response to a breach of the limits of firms' managerial resources, she mentions the forced partial divestment or total expropriation implemented by host governments to manage the balance of payment effects of foreign firms' operations (in relation to the profits remitted by foreign subsidiaries to their parent organizations) (Penrose, 1956).

${ }^{2}$ We also test for a mediating effect of performance in our models to explore this possibility.

${ }^{3}$ We would like to thank an anonymous reviewer for raising this issue.

${ }^{4} \mathrm{~A}$ second reason for assuming an effectively immediate release of managerial resources through divestment is related to the particular characteristics of horizontal divestment in the retail sector that make a linear or concave cost-of-adjustment function likely. The costs of adjusting a firms' capital stock have traditionally been assumed to grow exponentially with increasing levels of (dis-) investment in a particular period caused by the reorganization of organizational processes or the (re)training of employees (Rothschild, 1971). Under these conditions, firms spread their divestment activities over multiple periods, thereby slowing the release of (managerial) resources. In contrast, Rothschild (1971) demonstrates that there are no a priori reasons that this adjustment cost function should be convex instead of linear or concave. A concave function may be attributable to standardized processes and routines for deciding and implementing decisions about foreign investment and divestment, which remove firms' incentive to spread divestment over extended periods and therefore accelerate the release of resources. Case-based evidence based on large retailers' international expansion reveals the standardization and formalization of processes associated with international expansion (see for example, Swoboda, Schwarz, \& Hälsig, 2007). Given that horizontal expansion is likely to require similar managerial skills and resources - unlike vertical expansion (Kay, 1999) - the cost-of-adjustment function is likely to be linear or even concave in the case of retail divestment and the associated rapid release of managerial resources. Additionally, whereas manufacturing facilities may have been designed in particular manners or in particular locations and thus may be difficult to sell, prime locations for a particular retailer are likely to be prime locations for other retailers as well (i.e., not only the firm's direct competitors but also a wide range of other firms/retailers). Similarly, in the case of divestments in the primary/secondary sector, firms must sell or move machinery and equipment to other sites, which requires greater managerial attention. Therefore, the release of resources associated with foreign divestment in the retail sector may be more immediate than that possible through divestment in other sectors (Jackson, Mellahi, \& Sparks, 2005). We would like to thank one of the anonymous reviewers for highlighting our assumption regarding the shape of the cost-of-adjustment function.

${ }^{5}$ Other studies have used longer periods to calculate this measure (e.g., Chang \& Rhee, 2011). We decided to use the last two years of activity to measure internationalization speed because in the short-term firms cannot eliminate constraints on managerial resources by increasing managerial resources (Penrose, 1959).

${ }^{6}$ Table A1 (Appendix) shows the first-stage regression results for internationalization speed and the corresponding interaction terms.

${ }^{7}$ The distinction between low and high values of a moderator is commonly based on one standard deviation above and below the mean value of the moderator. Because the mean of our moderator is lower than its standard deviation, we follow prior research (e.g., Meschi, Ricard, \& Tapia Moore, 2017) and use $1 / 2$ standard deviation as the cut-off point. 
${ }^{8} \mathrm{We}$ measured performance as the ratio of net income to total assets. The results of this analysis are available from the authors.

${ }^{9}$ The results of this analysis are available from the authors.

\section{REFERENCES}

Agarwal, R., Audretsch, D., \& Sarkar, M. B. (2007). The process of creative construction: Knowledge spillovers, entrepreneurship, and economic growth. Strategic Entrepreneurship Journal, 1(3-4), 263-286.

Aiken, L. S., \& West, S. G. (1991). Multiple regression. Testing and interpreting interactions. Newbury Park: Sage.

Alexander, N., \& Myers, H. (2000). The retail internationalisation process. International Marketing Review, 17(4-5), $334-353$

Alexander, N., Quinn, B., \& Cairns, P. (2005). International retail divestment activity. International Journal of Retail \& Distribution Management, 33(1), 5-22.

Arregle, J.-L., Beamish, P. W., \& Hébert, L. (2009). The regional dimension of $\mathrm{MNEs}^{\prime}$ foreign subsidiary localization. Journal of International Business Studies, 40(1), 86-107.

Arregle, J.-L., Miller, T. L., Hitt, M. A., \& Beamish, P. W. (2016). How does regional institutional complexity affect MNE internationalization? Journal of International Business Studies, 47(6), 697-722.

Asmussen, C. G. (2012). Foundations of regional versus global strategies of MNEs. In A. Verbeke \& H. Merchant (Eds.), Handbook of research on international strategic management. Cheltenham, UK: Edward Elgar.

Banalieva, E. R., \& Dhanaraj, C. (2013). Home-region orientation in international expansion strategies. Journal of International Business Studies, 44(2), 89-116.

Barkema, H. G., Bell, J. H. J., \& Pennings, J. M. (1996). Foreign entry, cultural barriers, and learning. Strategic Management Journal, 17(2), 151-166.

Baron, R. M., \& Kenny, D. A. (1986). The moderator-mediator variable distinction in social psychological research: Conceptual, strategic, and statistical considerations. Journal of Personality and Social Psychology, 51(6), 1173-1182.

Bascle, G. (2008). Controlling for endogeneity with instrumental variables in strategic management research. Strategic Organization, 6, 285-327.

Baum, C. F., Schaffer, M. E., \& Stillman, S. (2007). Enhanced routines for instrumental variables/generalized method of moments estimation and testing. Stata Journal, 7(4), 465-506.

Baum, M., Schwens, C., \& Kabst, R. (2015). A latent class analysis of small firms' internationalization patterns. Journal of World Business, 50(4), 754-768.

Beamish, P. W., \& Lupton, N. C. (2016). Cooperative strategies in international business and management: Reflections on the past 50 years and future directions. Journal of World Business, 51(1), 163-175.

Belderbos, R., \& Zou, J. (2006). Foreign investment, divestment and relocation by Japanese electronics firms in East Asia. Asian Economic Journal, 20(1), 1-27.

Belderbos, R., \& Zou, J. (2009). Real options and foreign affiliate divestments: A portfolio perspective. Journal of International Business Studies, 40(4), 600-620.

Benito, G. R. G. (1997). Divestment of foreign production operations. Applied Economics, 29(10), 1365-1377.

Benito, G. R. G. (2005). Divestment and international business strategy. Journal of Economic Geography, 5(2), 235-251.

Benito, G. R. G., \& Welch, L. S. (1997). De-internationalization. Management International Review, 37(2), 7-25.

Berry, H. (2010). Why do firms divest? Organization Science, $27(2), 380-396$.
${ }^{10}$ We would like to thank one of the reviewers for highlighting this issue.

Berry, H. (2013). When do firms divest foreign operations? Organization Science, 24(1), 2461-2462.

Boddewyn, J. J. (1979). Foreign divestment. Magnitude and factors. Journal of International Business Studies, 10(1), 21-27.

Boddewyn, J. J. (1983a). Foreign and domestic divestment and investment decisions. Like or unlike? Journal of International Business Studies, 14(3), 23-35.

Boddewyn, J. J. (1983b). Foreign direct divestment theory: Is the reverse of FDI theory? Weltwirtschaftliches Archiv-Review of World Economics, 119(2), 345-355.

Cairns, P., Doherty, A. M., Alexander, N., \& Quinn, B. (2008). Understanding the international retail divestment process. Journal of Strategic Marketing, 16(2), 111-128.

Casillas, J. C., \& Moreno-Menéndez, A. M. (2014). Speed of the internationalization process: The role of diversity and depth in experiential learning. Journal of International Business Studies, 45(1), 1-17.

Chan, C. M., Makino, S., \& Isobe, T. (2006). Interdependent behavior in foreign direct investment: The multi-level effects of prior entry and prior exit on foreign market entry. Journal of International Business Studies, 37(5), 642-665.

Chang, S.-J., Chung, J., \& Moon, J. J. (2013). When do wholly owned subsidiaries perform better than joint ventures? Strategic Management Journal, 34(3), 317-337.

Chang, S.-J., \& Rhee, J. H. (2011). Rapid FDI expansion and firm performance. Journal of International Business Studies, 42(8), 979-994.

Chang, S. J., \& Singh, H. (1999). The impact of modes of entry and resource fit on modes of exit by multibusiness firms. Strategic Management Journal, 20(11), 1019-1035.

Chen, T. J., \& Wu, G. (1996). Determinants of divestment of FDI in Taiwan. Weltwirtschaftliches Archiv-Review of World Economics, 132(1), 172-184.

Clarke, J. E., Tamaschke, R., \& Liesch, P. W. (2013). International experience in international business research: A conceptualization and exploration of key themes. International Journal of Management Reviews, 15(3), 265-279.

Collinson, S., \& Rugman, A. M. (2008). The regional nature of Japanese multinational business. Journal of International Business Studies, 39(2), 215-230.

Cui, L., Meyer, K. E., \& Hu, H. W. (2014). What drives firms' intent to seek strategic assets by foreign direct investment? A study of emerging economy firms. Journal of World Business, 49(4), 488-501.

Dai, L., Eden, L., \& Beamish, P. W. (2013). Place, space, and geographical exposure: Foreign subsidiary survival in conflict zones. Journal of International Business Studies, 44(6), 554-578.

Davidson, R., \& MacKinnon, J. G. (1993). Estimation and inference in econometrics. New York: Oxford University Press.

Dawson, J. (2001). Strategy and opportunism in european retail internationalization. British Journal of Management, 12(4), 253.

Delios, A., \& Beamish, P. W. (2001). Survival profitability: The roles of experience and intangible assets in foreign subsidiary performance. Academy of Management Journal, 44(5), 1028-1038.

Gao, G. Y., \& Pan, Y. (2010). The pace of MNEs' sequential entries: Cumulative entry experience and the dynamic process. Journal of International Business Studies, 41(9), 1572-1580. 
Ghertman, M. (1988). Foreign subsidiary and parents' roles during strategic investment and divestment decisions. Journal of International Business Studies, 19(1), 47-67.

Gielens, K., \& Dekimpe, M. G. (2007). The entry strategy of retail firms into transition economies. Journal of Marketing, 71(2), 196-212.

Gripsrud, G., \& Benito, G. R. G. (2005). Internationalization in retailing: Modeling the pattern of foreign market entry. Journal of Business Research, 58(12), 1672-1680.

Gunawan, J., \& Rose, E. L. (2014). Absorptive capacity development in Indonesian exporting firms: How do institutions matter? International Business Review, 23(1), 45-54.

Håkanson, L., \& Kappen, P. (2017). The 'Casino Model' of internationalization: An alternative Uppsala paradigm. Journal of International Business Studies, 48(9), 1103-1113.

Hamilton, R. T., \& Chow, Y. K. (1993). Why managers divest: Evidence from New Zealand's largest companies. Strategic Management Journal, 14(6), 479-484.

Haynes, M., Thompson, S., \& Wright, M. (2002). The impact of divestment on firm performance: Empirical evidence from a panel of UK companies. Journal of Industrial Economics, 50(2), 173-196.

Helfat, C. E., \& Eisenhardt, K. M. (2004). Inter-temporal economies of scope, organizational modularty, and the dynamics of diversification. Strategic Management Journal, 25(13), 1217-1232.

Hennan, D., \& Perlmutter, H. (1979). Multinational organizational development: $A$ social architecture perspective. Reading, MA: Addison-Wesley.

Hennart, J.-F., Kim, D.-J., \& Zeng, M. (1998). The impact of joint venture status on the longevity of lapanese stakes in US manufacturing affiliates. Organization Science, 9(3), 382-395.

Hitt, M. A. (1997). International diversification: Effects on innovation and firm performance in product-diversified firms. Academy of Management Journal, 40(4), 767-798.

Hofstede, G. (2001). Cultures consequences: Comparing values, behaviors, institiutions and organizations across nations. Thousand Oaks, London, New Delhi: Sage.

Hoskisson, R. E., Johnson, R. A., \& Moesel, D. D. (1994). Corporate divestiture intensity in restructuring firms: Effects of governance, strategy, and performance. Academy of Management Journal, 37(5), 1207-1251.

Hoskisson, R. E., \& Turk, T. A. (1990). Corporate restructuring: Governance and control limits of the internal capital market. Academy of Management Review, 15(3), 459-477.

Huang, Y., \& Sternquist, B. (2007). Retailers' foreign market entry decisions: An institutional perspective. International Business Review, 16(5), 613-629.

Hutzschenreuter, T., Kleindienst, I., \& Lange, S. (2014). Added psychic distance stimuli and MNE performance: Performance effects of added cultural, governance, geographic, and economic distance in MNEs' international expansion. Journal of International Management, 20(1), 38-54.

Hutzschenreuter, T., \& Matt, T. (2017). MNE internationalization patterns, the roles of knowledge stocks, and the portfolio of MNE subsidiaries. Journal of International Business Studies, 48(9), 1131-1150.

Hutzschenreuter, T., \& Voll, J. C. (2008). Performance effects of "added cultural distance" in the path of international expansion: The case of German multinational enterprises. Journal of International Business Studies, 39(1), 53-70.

Hutzschenreuter, T., Voll, J. C., \& Verbeke, A. (2011). The impact of added cultural distance and cultural diversity on international expansion patterns: A Penrosean perspective. Journal of Management Studies, 48(2), 305-329.

Jackson, P., Mellahi, K., \& Sparks, L. (2005). Shutting up shop: Understanding the international exit process in retailing. Service Industries Journal, 25(3), 355-371.

Jacquemin, A. P., \& Berry, C. H. (1979). Entropy measure of diversification and corporate growth. Journal of Industrial Economics, 27(4), 359-369.
Jiang, R. J., Beamish, P. W., \& Makino, S. (2014). Time compression diseconomies in foreign expansion. Journal of World Business, 49(1), 114-121.

Kay, N. (1999). Hercules and Penrose. Contributions to Political Economy, 18(1), 67-86.

Kogut, B., \& Singh, H. (1988). The effect of national culture on the choice of entry mode. Journal of International Business Studies, 19(3), 411-432.

Levinthal, D. A., \& Wu, B. (2010). Opportunity costs and nonscale free capabilities: Profit maximization, corporate scope, and profit margins. Strategic Management Journal, 31(7), 780-801.

Levy, O., Beechler, S., Taylor, S., \& Boyacigiller, N. A. (2007). What we talk about when we talk about 'global mindset': Managerial cognition in multinational corporations. Journal of International Business Studies, 38(2), 231-258.

Li, J. (1995). Foreign entry and survival: Effects of strategic choices on performance in international markets. Strategic Management Journal, 16(5), 333-351.

Luo, Y., \& Peng, M. W. (1999). Learning to compete in a transition ecconomy: Experience, environment, and performance. Journal of International Business Studies, 30(2), 269.

Mahoney, J. T., \& Pandian, J. R. (1992). The resource-based view within the conversation of strategic management. Strategic Management Journal, 13(5), 363-380.

Mariotti, S., \& Piscitello, L. (1999). Is divestment a failure or part of a restructuring strategy? The case of Italian transnational corporations. Transnational Corporations, 8(3), 25-54.

Markides, C. C. (1992). Consequences of corporate refocusing: Ex ante evidence. Academy of Management Journal, 35(2), 398-412.

Markides, C. C. (1995). Diversification, refocusing and economic performance. Cambridge, MA: MIT Press.

Mendenhall, M. E., Dunbar, E., \& Oddou, G. R. (1987). Expatriate selection, training and career-pathing: A review and critique. Human Resource Management, 26(3), 331-345.

Meschi, P.-X., Ricard, A., \& Tapia Moore, E. (2017). Fast and furious or slow and cautious? The joint impact of age at internationalization, speed, and risk diversity on the survival of exporting firms. Journal of International Management, 23(3), 279-291.

Mohr, A., \& Batsakis, G. (2014). Intangible assets, international experience and the internationalisation speed of retailers. International Marketing Review, 31(6), 601-620.

Mohr, A. T., Fastoso, F., Wang, C., \& Shirodkar, V. (2014). Testing the regional performance of multinational enterprises in the retail sector: The moderating effects of timing, speed and experience. British Journal of Management, 25(Special Issue), 100-125.

Morschett, D., Donath, A., Swoboda, B., \& Schramm-Klein, H. (2011). What do we really know about antecedents of international divestment? A systematic review. Paper presented at European International Business Academy (EIBA) Annual Conference, Bucharest.

Mousa, F.-T., \& Reed, R. (2013). The impact of slack resources on high-tech IPOs. Entrepreneurship Theory and Practice, 37(5), 1123-1147.

Oh, C. H., \& Rugman, A. M. (2012). Regional integration and the international strategies of large European firms. International Business Review, 21(3), 493-507.

Oh, C. H., Sohl, T., \& Rugman, A. M. (2015). Regional and product diversification and the performance of retail multinationals. Journal of International Management, 21(3), 220-234.

Palmer, M. (2005). Retail multinational learning: A case study of Tesco. International Journal of Retail \& Distribution Management, 33(1), 23-48.

Palmer, M., \& Quinn, B. (2007). The nature of international retail divestment: Insights from Ahold. International Marketing Review, 24(1), 26-45. 
Pattnaik, C. \& Lee, J. Y. (2014). Distance and divestment of Korean MNC affiliates: The moderating role of entry mode and experience. Asia Pacific Business Review, 20(1), 174-196.

Penrose, E. (1956). Foreign investment and the growth of the firm. Economic lournal, 66, 220-235.

Penrose, E. (1959). The theory of the growth of the firm. Oxford: Oxford University Press.

Penrose, E. T. (1995). Foreword to the third edition. In E. T. Penrose (Ed.), The theory of the growth of the firm. Oxford: Oxford University Press.

Pitelis, C. (2007). Edith Penrose and a learning-based perspective on the MNE and OLI. Management International Review, 47(2), 207-219.

Pitelis, C. \& Verbeke, A. (2007). Edith Penrose and the future of the multinational enterprise: New research directions. Management International Review, 47(2), 139-149.

Qian, G., Li, L., \& Rugman, A. M. (2013). Liability of country foreignness and liability of regional foreignness: Their effects on geographic diversification and firm performance. Journal of International Business Studies, 44(6), 635-647.

Roberts, P. W., \& McEvily, S. (2005). Product-line expansion and resource cannibalization. Journal of Economic Behavior \& Organization, 57(1), 49-70.

Rothschild, M. (1971). On the cost of adjustment. Quarterly lournal of Economics, 85(4), 605-622.

Rugman, A. M. (2005). The regional multinationals. MNEs and "Global" Strategic management. Cambridge: Cambridge University Press.

Rugman, A. M., \& Verbeke, A. (2004). A perspective on regional and global strategies of multinational enterprises. Journal of International Business Studies, 35(1), 3-18.

Rugman, A. M., \& Verbeke, A. (2005). Towards a theory of regional multinationals: A transaction cost economics approach. Management International Review, 45(Special Issue 1): 5-17.

Rugman, A. M., \& Verbeke, A. (2007). Liabilities of regional foreignness and the use of firm-level versus country-level data: A response to Dunning et al. Journal of International Business Studies, 38(1), 200-205.

Slangen, A. H. L. (2016). The comparative effect of subnational and nationwide cultural variation on subsidiary ownership choices: The role of spatial coordination challenges and penrosean growth constraints. Economic Geography, 92(2), $145-171$.

Slater, M. (1980). The managerial limitation to the growth of firms. Economic Journal, 90(359), 520-528.

Song, S. (2014). Subsidiary divestment: The role of multinational flexibility. Management International Review, 54(1), 47-70.
Soule, S. A., Swaminathan, A., \& Tihanyi, L. (2014). The diffusion of foreign divestment from Burma. Strategic Management Journal, 35(7), 1032-1052.

Steen, J. T., \& Liesch, P. W. (2007). A note on Penrosean growth, resource bundles and the Uppsala model of internationalisation. Management International Review, 47(2), 193-206.

Sternquist, B. (2007). International retailing (2nd ed.). New York: Fairchild Books.

Stock, J., \& Yogo, M. (2005). Testing for weak instruments in linear IV regression. In D. W. K. Andrews (Ed.), Identification and inference for econometric models. New York: Cambridge University Press.

Swoboda, B., Schwarz, S., \& Hälsig, F. (2007). Towards a conceptual model of country market selection: Selection processes of retailers and C\&C wholesalers. International Review of Retail, Distribution and Consumer Research, 17(3), 253-282.

Tan, D. (2003). The limits to the growth of multinational firms in a foreign market. Managerial and Decision Economics, 24(8), 569-582.

Tan, D., \& Mahoney, J. T. (2005). Examining the Penrose effect in an international business context: The dynamics of Japanese firm growth in US industries. Managerial and Decision Economics, 26(2), 113-127.

Tran, H. T., Santarelli, E., \& Zaninotto, E. (2015). Efficiency or bounded rationality? Drivers of firm diversification strategies in Vietnam. Journal of Evolutionary Economics, 25(5), 983-1010.

Tsang, E. W. K., \& Yip, P. S. L. (2007). Economic distance and the survival of foreign direct investments. Academy of Management Journal, 50(5), 1156.

Verbeke, A., \& Asmussen, C. G. (2016). Global, local, or regional? The locus of MNE strategies. The Journal of Management Studies, 53(6), 1051

Verbeke, A., \& Yuan, W. (2007). Entrepreneurship in multinational enterprises: A Penrosean perspective. Management International Review, 47(2), 241-258.

Vermeulen, F., \& Barkema, H. (2002). Pace, rhythm, and scope: Process dependence in building a profitable multinational corporation. Strategic Management Journal, 23(7), 637-653.

Wan, W. P., Chen, H. S., \& Yiu, D. W. (2015). Organizational image, identity, and international divestment. A theoretical examination. Global Strategy Journal, 5(3), 205-222.

Wiersema, M. F., \& Bowen, H. P. (2008). Corporate diversification: The impact of foreign competition, industry globalization, and product diversification. Strategic Management Journal, 29(2), 115-132.

Wooldridge, J. M. (2010). Econometric analysis of cross section and panel data. Cambridge, MA: MIT Press. 


\section{APPENDIX}

Table A1 First-stage regression estimates for Model 2

\begin{tabular}{|c|c|c|c|}
\hline & $\begin{array}{l}\text { Internationalization } \\
\text { speed }\end{array}$ & $\begin{array}{l}\text { Internationalization } \\
\text { speed } \times \text { intra-regional } \\
\text { concentration }\end{array}$ & $\begin{array}{l}\text { Internationalization } \\
\text { speed } \times \text { international } \\
\text { experience }\end{array}$ \\
\hline \multirow[t]{2}{*}{ Intra-regional concentration } & $1.878711^{\star *}$ & -3.968645 & $186.7146^{* * *}$ \\
\hline & $(0.766787)$ & $(14.21022)$ & $(64.3359)$ \\
\hline \multirow[t]{2}{*}{ International experience } & $-0.4398158^{* *}$ & $7.511871^{* *}$ & $-44.05555^{\star * *}$ \\
\hline & $(0.1974992)$ & $(3.660086)$ & $(16.57082)$ \\
\hline \multirow[t]{2}{*}{ Geographic scope } & $8.194945^{* * *}$ & $-76.40024^{* * *}$ & $153.2954^{\star}$ \\
\hline & $(1.025844)$ & $(19.0111)$ & $(86.07163)$ \\
\hline \multirow[t]{2}{*}{ Market share } & $132.1781^{* * *}$ & $1396.604^{* *}$ & -4469.75 \\
\hline & $(35.83801)$ & $(664.1557)$ & $(3006.925)$ \\
\hline \multirow[t]{2}{*}{ Intra-regional concentration $\times$ geographic scope } & $-0.1298315^{\star \star *}$ & $5.811529 * * *$ & $-15.62304^{* * *}$ \\
\hline & $(0.0389214)$ & $(0.7212983)$ & $(3.265635)$ \\
\hline \multirow[t]{2}{*}{ International experience $\times$ geographic scope } & -0.0055237 & 0.0767519 & $4.273^{\star \star \star}$ \\
\hline & $(0.0045565)$ & $(0.0844414)$ & $(0.3823032)$ \\
\hline \multirow[t]{2}{*}{ Intra-regional concentration $\times$ market share } & $-16.85038^{\star \star *}$ & $537.5712^{* * *}$ & $-1385.286^{\star * *}$ \\
\hline & $(3.536042)$ & $(65.5305)$ & $(296.6854)$ \\
\hline \multirow{2}{*}{ International experience $\times$ market share } & -0.5819516 & 11.23339 & $167.7985^{* * *}$ \\
\hline & $(0.4714778)$ & $(8.737501)$ & $(39.55851)$ \\
\hline \multirow[t]{2}{*}{ Leverage } & -0.461934 & -0.6398853 & -60.018 \\
\hline & $(0.536843)$ & $(9.94886)$ & $(45.04286)$ \\
\hline \multirow[t]{2}{*}{ Intangible assets } & 0.0333452 & 18.40021 & -81.34497 \\
\hline & $(0.6319102)$ & $(11.71066)$ & $(53.01931)$ \\
\hline \multirow[t]{2}{*}{ Age } & 0.1125892 & -1.072202 & 13.09719 \\
\hline & $(0.1692968)$ & $(3.137435)$ & $(14.20455)$ \\
\hline \multirow[t]{2}{*}{ Size } & -2.873526 & 39.36577 & -61.14629 \\
\hline & $(2.991827)$ & $(55.44501)$ & $(251.024)$ \\
\hline \multirow[t]{2}{*}{ Performance } & 0.8542302 & 14.1868 & -21.01091 \\
\hline & $(0.9483208)$ & $(17.57443)$ & $(79.56718)$ \\
\hline \multirow[t]{2}{*}{ Cash slack } & $36.02735^{\star * *}$ & -15.85912 & $1828.88^{* *}$ \\
\hline & $(10.89355)$ & $(201.881)$ & $(914.0039)$ \\
\hline \multirow[t]{2}{*}{ Product diversification } & -0.0414608 & -17.55552 & -275.6283 \\
\hline & $(15.73761)$ & $(291.6518)$ & $(1320.436)$ \\
\hline \multirow[t]{2}{*}{ Competitive pressure } & -0.0685651 & $8.508207^{* *}$ & -18.35687 \\
\hline & $(0.2202366)$ & $(4.08146)$ & $(18.47856)$ \\
\hline \multirow[t]{2}{*}{ Added cultural distance } & -8.881721 & -0.48 .47275 & -270.0238 \\
\hline & $(7.495387)$ & $(138.9057)$ & $(628.8872)$ \\
\hline \multirow[t]{2}{*}{ Home market size } & $-13.77944^{*}$ & -134.2378 & -237.6762 \\
\hline & $(7.362938)$ & $(136.4511)$ & $(617.7743)$ \\
\hline \multirow[t]{2}{*}{ Acquisition } & $57.36331^{\star * *}$ & $-659.4944^{\star}$ & 1911.252 \\
\hline & (19.53963) & $(362.1116)$ & $(1639.439)$ \\
\hline \multirow[t]{2}{*}{ International franchise } & -5.597447 & 314.331 & -1779.642 \\
\hline & $(17.65684)$ & $(327.2194)$ & $(1481.466)$ \\
\hline \multirow[t]{2}{*}{ Triad 1 (America) } & 28.91021 & 174.8478 & -1131.31 \\
\hline & $(24.60864)$ & $(456.0512)$ & $(2064.744)$ \\
\hline \multirow[t]{2}{*}{ Triad 2 (Europe) } & 15.76576 & 106.4605 & -46.30084 \\
\hline & $(19.5501)$ & $(362.3056)$ & $(1640.317)$ \\
\hline Constant & $437.5239^{* *}$ & 2622.083 & $14,164.22$ \\
\hline & $(215.7085)$ & (3997.545) & $18,098.64$ \\
\hline Wald $\chi^{2}$ & $404.000^{* * *}$ & $578.000^{\star * *}$ & $1267.000^{* * *}$ \\
\hline Observations & 730 & 730 & 730 \\
\hline Number of firms & 120 & 120 & 120 \\
\hline
\end{tabular}

${ }^{* * *} p<0.01,{ }^{* *} p<0.05,{ }^{*} p<0.10$. Two-tailed tests are used. Standard errors are in parentheses. All models include year and industry dummies. All models are lagged one year. Triad 3 (Asia) acts as the reference Triad category. 
Table A2 2SLS IV regression estimates for foreign divestment (alternative speed measure)

\begin{tabular}{|c|c|c|}
\hline & Model A2.1 & Model A2.2 \\
\hline Internationalization speed & $\begin{array}{l}0.00969^{*} \\
(0.00610)\end{array}$ & $\begin{array}{l}0.00876^{*} \\
(0.00618)\end{array}$ \\
\hline Internationalization speed $\times$ intra-regional concentration & & $\begin{array}{l}-0.00124^{\star * *} \\
(0.000335)\end{array}$ \\
\hline Internationalization speed $\times$ international experience & & $\begin{array}{l}-9.66 e-05^{* *} \\
(4.67 e-05)\end{array}$ \\
\hline Intra-regional concentration & $\begin{array}{l}-0.0248^{* *} \\
(0.0103)\end{array}$ & $\begin{array}{l}-0.00956 \\
(0.0111)\end{array}$ \\
\hline International experience & $\begin{array}{l}1.52 e-05 \\
(0.00232)\end{array}$ & $\begin{array}{l}0.00314 \\
(0.00393)\end{array}$ \\
\hline Leverage & $\begin{array}{l}-0.000593 \\
(0.0111)\end{array}$ & $\begin{array}{l}-0.00349 \\
(0.0115)\end{array}$ \\
\hline Intangible assets & $\begin{array}{l}-0.00161 \\
(0.0144)\end{array}$ & $\begin{array}{l}0.000233 \\
(0.0148)\end{array}$ \\
\hline Age & $\begin{array}{l}0.00340 \\
(0.00370)\end{array}$ & $\begin{array}{l}0.000502 \\
(0.00389)\end{array}$ \\
\hline Size & $\begin{array}{l}0.0741 \\
(0.0621)\end{array}$ & $\begin{array}{l}0.142^{* *} \\
(0.0682)\end{array}$ \\
\hline Performance & $\begin{array}{l}0.00298 \\
(0.0199)\end{array}$ & $\begin{array}{l}0.00754 \\
(0.0201)\end{array}$ \\
\hline Cash slack & $\begin{array}{l}-0.243 \\
(0.302)\end{array}$ & $\begin{array}{l}-0.281 \\
(0.303)\end{array}$ \\
\hline Product diversification & $\begin{array}{l}0.0289 \\
(0.343)\end{array}$ & $\begin{array}{l}0.220 \\
(0.357)\end{array}$ \\
\hline Competitive pressure & $\begin{array}{l}2.20 \mathrm{e}-05 \\
(0.00414)\end{array}$ & $\begin{array}{l}0.00257 \\
(0.00431)\end{array}$ \\
\hline Acquisition & $\begin{array}{l}-0.0746 \\
(0.421)\end{array}$ & $\begin{array}{l}-0.228 \\
(0.414)\end{array}$ \\
\hline International franchise & $\begin{array}{l}0.279 \\
(0.383)\end{array}$ & $\begin{array}{l}0.217 \\
(0.400)\end{array}$ \\
\hline Added cultural distance & $\begin{array}{l}-0.126 \\
(0.157)\end{array}$ & $\begin{array}{l}-0.164 \\
(0.162)\end{array}$ \\
\hline Home market size & $\begin{array}{l}-0.179 \\
(0.153)\end{array}$ & $\begin{array}{l}-0.164 \\
(0.160)\end{array}$ \\
\hline Triad 1 (America) & $\begin{array}{l}0.862 \\
(0.539)\end{array}$ & $\begin{array}{l}0.823 \\
(0.553)\end{array}$ \\
\hline Triad 2 (Europe) & $\begin{array}{l}0.758^{*} \\
(0.433)\end{array}$ & $\begin{array}{l}0.873 * \\
(0.447)\end{array}$ \\
\hline Constant & $\begin{array}{l}3.450 \\
(4.494)\end{array}$ & $\begin{array}{l}1.585 \\
(4.751)\end{array}$ \\
\hline $\mathrm{R}^{2}$ & 0.25 & 0.26 \\
\hline Observations & 935 & 935 \\
\hline Number of firms & 120 & 120 \\
\hline
\end{tabular}

${ }^{* * *} p<0.01,{ }^{* *} p<0.05,{ }^{*} p<0.10$. One-tailed tests are used for hypothesized variables; two-tailed tests are used for controls. Standard errors are in parentheses. All models include year and industry dummies. All models are lagged one year. Instruments used in the 2SLS regression (Model A2): Geographic scope, geographic scope $\times$ intra-regional concentration, geographic scope $\times$ international experience, market share, market share $\times$ intra-regional concentration, and market share $\times$ international experience. Independent and instrumental variables are mean-centered. Triad 3 (Asia) acts as the reference Triad category. 
Table A3 2SLS IV regression estimates for foreign divestment (2-year lags)

\begin{tabular}{|c|c|c|}
\hline & Model A3.1 & Model A3.2 \\
\hline \multirow[t]{2}{*}{ Internationalization speed } & $0.00562^{* * *}$ & $0.00441^{* *}$ \\
\hline & $(0.00237)$ & $(0.00263)$ \\
\hline \multirow[t]{2}{*}{ Internationalization speed $\times$ intra-regional concentration } & & $-0.000275^{\star *}$ \\
\hline & & $(0.000160)$ \\
\hline \multirow[t]{2}{*}{ Internationalization speed $\times$ international experience } & & $-3.16 \mathrm{e}-05^{\star}$ \\
\hline & & $(2.32 \mathrm{e}-05)$ \\
\hline \multirow{2}{*}{ Intra-regional concentration } & 0.00257 & 0.0304 \\
\hline & $(0.0116)$ & $(0.0192)$ \\
\hline \multirow[t]{2}{*}{ International experience } & 0.00240 & 0.00703 \\
\hline & $(0.00235)$ & $(0.00430)$ \\
\hline \multirow[t]{2}{*}{ Leverage } & -0.00584 & -0.00971 \\
\hline & $(0.0124)$ & $(0.0126)$ \\
\hline \multirow[t]{2}{*}{ Intangible assets } & 0.00875 & 0.00956 \\
\hline & $(0.0143)$ & $(0.0146)$ \\
\hline \multirow[t]{2}{*}{ Age } & 0.00453 & 0.00362 \\
\hline & $(0.00389)$ & $(0.00394)$ \\
\hline \multirow[t]{2}{*}{ Size } & $0.148^{* *}$ & $0.171^{* *}$ \\
\hline & $(0.0671)$ & $(0.0685)$ \\
\hline \multirow[t]{2}{*}{ Performance } & -0.0164 & -0.0152 \\
\hline & $(0.0265)$ & $(0.0264)$ \\
\hline \multirow[t]{2}{*}{ Cash slack } & -0.320 & -0.288 \\
\hline & $(0.279)$ & $(0.283)$ \\
\hline \multirow{2}{*}{ Product diversification } & -0.121 & -0.136 \\
\hline & $(0.353)$ & $(0.353)$ \\
\hline \multirow[t]{2}{*}{ Competitive pressure } & 0.00297 & 0.00290 \\
\hline & $(0.00474)$ & $(0.00474)$ \\
\hline \multirow[t]{2}{*}{ Acquisition } & 0.113 & 0.0159 \\
\hline & $(0.474)$ & $(0.471)$ \\
\hline \multirow[t]{2}{*}{ International franchise } & -0.113 & -0.121 \\
\hline & $(0.383)$ & $(0.389)$ \\
\hline \multirow[t]{2}{*}{ Added cultural distance } & -0.196 & -0.205 \\
\hline & $(0.162)$ & $(0.168)$ \\
\hline \multirow[t]{2}{*}{ Home market size } & 0.0264 & -0.0311 \\
\hline & $(0.161)$ & $(0.165)$ \\
\hline \multirow{2}{*}{ Triad 1 (America) } & 0.475 & 0.563 \\
\hline & $(0.558)$ & $(0.567)$ \\
\hline \multirow[t]{2}{*}{ Triad 2 (Europe) } & 0.432 & 0.442 \\
\hline & $(0.442)$ & $(0.446)$ \\
\hline \multirow[t]{2}{*}{ Constant } & -3.492 & -1.900 \\
\hline & $(4.743)$ & $(4.865)$ \\
\hline$R^{2}$ & 0.17 & 0.20 \\
\hline Observations & 614 & 614 \\
\hline Number of firms & 120 & 120 \\
\hline
\end{tabular}

${ }^{* * *} p<0.01,{ }^{* *} p<0.05,{ }^{*} p<0.10$. One-tailed tests are used for hypothesized variables; two-tailed tests are used for controls. Standard errors are in parentheses. All models include year and industry dummies. All models are lagged 2 years. Instruments used in the 2SLS regression (Model A4): Geographic scope, geographic scope $\times$ intra-regional concentration, geographic scope $\times$ international experience, market share, market share $\times$ intra-regional concentration, and market share $\times$ international experience. Independent and instrumental variables are mean-centered. Triad 3 (Asia) acts as the reference Triad category. 


\section{ABOUT THE AUTHORS}

Alex Mohr is a Professor of International Business at the Vienna University of Economics and Business. His research interests include market entry strategies, corporate political strategies, and international human resource management.

Georgios Batsakis is an Assistant Professor of International Business at ALBA Graduate Business School, The American College of Greece. He is also a Lecturer in International Business at Brunel Business School, Brunel University London. His research focuses on internationalization processes and foreign market entry strategies of multinational enterprises.
Zita Stone is a Senior Lecturer at the University of Kent. Her research interests include strategic management, international business management, the internationalization process of SMEs, and institutional differences in cross-cultural contexts.

Open Access This article is distributed under the terms of the Creative Commons Attribution 4.0 International License (http://creativecommons. org/licenses/by/4.0/), which permits unrestricted use, distribution, and reproduction in any medium, provided you give appropriate credit to the original author(s) and the source, provide a link to the Creative Commons license, and indicate if changes were made. 